\title{
Mantle-like Trace Element Composition of Petroleum - Contributions from Serpentinizing Peridotites
}

\author{
Peter Szatmari ${ }^{1}$, Teresa Cristina O. da Fonseca ${ }^{1}$ and Norbert F. Miekeley ${ }^{2}$ \\ 1 Petrobras Research Center (CENPES), Rio de Janeiro, Brazil 21941-915, \\ 2PUC-Rio, Rio de Janeiro, \\ Brazil
}

\section{Introduction}

The origin of trace metals in petroleum is intimately connected with the origin of petroleum itself, one of the most exciting topics in chemistry and geology for the past 150 years. Because of its fluidity and consequent migration, the origin of petroleum is more difficult to interpret than that of most rocks. Biogenic and abiogenic models developed side by side, each championed by some of the greatest names in chemistry and geology. According to biogenic models, petroleum forms by thermal breakdown, in the presence of water, of complex, ultimately biogenic organic polymers (kerogen) (Tissot \& Welte, 1984; Lewan, 1997). Conversely, according to abiogenic models, petroleum forms by reductive polymerization of simple carbon compounds such as $\mathrm{CO}$ and $\mathrm{CO}_{2}$. Experiments and calculations indicate that such polymerization is thermodynamically stable only at high temperatures and pressures (above $1300^{\circ} \mathrm{C}$ and $30 \mathrm{kbar}$; Kenney et al., 2002) but it takes place also at low temperatures $\left(<400^{\circ} \mathrm{C}\right)$ and low pressures in the presence of metallic hydrogenation catalysts in the Fischer-Tropsch-type synthesis, FTTS (Fischer, 1926; Szatmari, 1989).

Although the biogenic, organic model has been the one generally accepted by the petroleum industry almost since its birth, abiogenic, inorganic models recurrently emerge, proposed by geologists and, more often, chemists.

Major contribution to oil deposits of hydrogen and hydrocarbon liquids formed by FTTS during serpentinization was suggested by Szatmari (1989). The process was demonstrated by the discoveries of the Rainbow (Holm and Charlou, 2001) and Lost City (Kelley et al., 2001; Früh-Green et al, 2003; Kelley, 2005; Proskurowski et al., 2008; Bach and Früh-Green, 2010) hydrothermal fields at the Mid-Atlantic ridge, where hydrothermal plumes rising over serpentinizing peridotites contain abundant hydrogen, methane, and aliphatic hydrocarbons in the $\mathrm{C}_{16}-\mathrm{C}_{29}$ range, formed by FTTS. This finding, together with the discovery of aliphatic and cyclic hydrocarbons in the Orgueuil meteorite and, more recently, in the pristine Tagish Lake meteorite (Pizzarello et al., 2001; Nakamura et al., 2003), as well as new studies on hydrocarbon stability at high P-T conditions (Kenney et al., 2002), gave renewed stimulus to the abiogenic models. The Tagish Lake meteorite is a new type of water and carbon-rich Type 2 carbonaceous chondrite that contains about $5 \%$ total carbon, of 
which the organic carbon reaches $1.3 \mathrm{wt}$. \%; the temperature of the meteorite has not risen above $120^{\circ} \mathrm{C}$ since the formation of the organics (Brown et al.,2000; Nakamura et al., 2003).

\section{Trace metals in oils: Sedimentary-biogenic source}

The most abundant trace elements in petroleum are V, Ni, and Fe. Treibs $(1934,1935)$ was the first to demonstrate the presence of metalloporphyrins of $\mathrm{V}$ and $\mathrm{Fe}$ in crude oil, bitumens, coals and shales; those of $\mathrm{Ni}$ were identified later. The study of trace metals in petroleum was early extended to elements other than $\mathrm{V}$ and $\mathrm{Ni}$, whose molecular species were still largely unknown (Filby \& Olsen, 1994). Ball et al. (1960) analyzed 28 trace elements in 24 U.S. oils. Filby \& Shah (1975) determined a wide range of trace metals using neutron activation analysis. $\mathrm{Cr}, \mathrm{Fe}, \mathrm{Co}, \mathrm{Cu}, \mathrm{Zn}$, and $\mathrm{Hg}$ were found in Tertiary California oil to occur in non-porphyrin form, similar to that of $\mathrm{Ni}$ and $\mathrm{V}$, incorporated into the asphaltene sheets through complexing at holes bordered by N, S, or O atoms (Filby, 1975). Jones (1977) compiled data for 29 metals in oils worldwide. Curiale (1987) analyzed ten transition metals in 82 heavy crude oils and 21 solid bitumens from unspecified locations worldwide.

Major works on metals in petroleum include the pioneering contribution of Yen and coworkers (1975), analytical studies by Jones (1977), reviews by Valkovic (1978), Barwise \& Whitehead (1983), and extensive studies by Filby and coworkers $(1975,1987,1994)$.). Lewan \& Maynard (1982) and Lewan (1984) interpreted V-Ni proportionality in petroleum by the varying availability of these metals controlled by varying $\mathrm{pH}-\mathrm{E}_{\mathrm{H}}$ in the sedimentary environment. Curiale $(1987,1993)$ pointed to the importance of the biota as a possible source of the metals. Modern techniques of ICP-MS and others resulted in an abundance of data, still incompletely interpreted.

Treibs (1934, 1935) showed that these porphyrins derive from bacterial and plant chlorophylls, and to a lesser extent from hemins, which during sedimentation lose their original chelating metals (respectively $\mathrm{Mg}$ and $\mathrm{Fe}$ ) and become chelated by $\mathrm{V}$ and other metals. 2 to $54 \%$ of the vanadium and 1 to $47 \%$ of the nickel in crude oils was reported to occur as extractable metalloporphyrins (Filby \& Van Berkel, 1987), while the rest is present in other, non-extractable, largely unknown organic structures. These may include metalloporphyrins strongly associated or incorporated into the asphaltenes so that they cannot be separated; metal naphthenates; metal species produced by the decomposition of metalloporphyrins during oil maturation; and metals complexed into the asphaltene structure by asphaltene functionalities (Filby, 1994).

The source of $\mathrm{V}, \mathrm{Ni}$, and $\mathrm{Fe}$ in the oils was also suggested to lie in the fossil organic matter (Treibs 1934, 1935; Yen, 1975), because average transition metal concentrations in crude oil and marine organisms are generally close, within an order of magnitude of one another (Jones 1977, Curiale, 1987), whereas transition metal concentrations in seawater are several (three or more) orders of magnitude lower, less than $1 \mathrm{ppb}$ for $\mathrm{V}$ and $0.48 \mathrm{ppb}$ for $\mathrm{Ni}$ (Quinby-Hunt \& Turekian, 1983).

Lewan \& Maynard (1982) and Lewan (1984), however, attributed the prevalence of Ni and V in the oils to selective chelation of the organic matter by sea water, in which most other tetravalent and trivalent ions that could form stable porphyrins (e.g., $\mathrm{Si}, \mathrm{Al}, \mathrm{Ti}$ ) are either almost absent or occur in oxygen-bearing hydrolyzed forms unavailable for chelation. Under reducing conditions many divalent metals precipitate as sulfides, becoming equally unavailable, whereas $\mathrm{Ni}(\mathrm{II})$ and $\mathrm{VO}(\mathrm{II})$ continue to be available, even if at low 
concentrations (Filby, 1994). Their availability in the depositional environment depends on $\mathrm{pH}$ and redox conditions and sulfide activity (Lewan \& Maynard, 1982; Lewan, 1984). In strongly reducing, anoxic environments, where the amount of bacterially generated sulfide exceeds the amount of available iron, vanadyl ions are available in the $\mathrm{pH} 4-8$ range whereas nickel is precipitated as aqueous nickel sulfide complexes, so that vanadyl-porphyrins would predominate in the sediments; expelled oils formed by catagenesis of organic matter in these sediments would have high $\mathrm{V} / \mathrm{Ni}$ ratios and high sulfur contents. Conversely, in less anoxic, $\mathrm{H}_{2} \mathrm{~S}$ poor environment vanadium occurs in the quinquivalent form, not available for metallation, whereas $\mathrm{Ni}^{2+}$ cations are available. This would favor the formation of nickelo-porphyrins; expelled oils thus would have low $\mathrm{V} / \mathrm{Ni}$ ratio and low sulfur content (Lewan, 1984; Filby, 1994). To compensate for the low concentrations of $\mathrm{Ni}$ and $\mathrm{V}$ in seawater, Lewan (1984) suggested that when sedimentation is slow, these ions migrate by diffusion from the entire overlying water column into the sediments, which they progressively enrich by becoming selectively retained by the porphyrins.

This model of synsedimentary metallation was somewhat modified when evidence from the Deep Sea Drilling Project (Louda \& Baker, 1981; Baker \& Louda, 1986) indicated that demetallation of chlorophyll and chelation of porphyrins by $\mathrm{V}$ and $\mathrm{Ni}$ occur later during diagenesis, at temperatures over $40^{\circ} \mathrm{C}$ and significantly below the sediment-water interface, when the compacting buried sediments are no more in open contact with the overlying water column. It was therefore suggested that metallation of organic species during diagenesis takes place in ion exchange sites of active clay mineral surfaces that retain high concentrations of metal ions acquired from the depositional environment (Filby \& Van Berkel, 1987; Filby, 1994). The USGS Central Region Mineral Resources Team was assessing metal partitioning during hydrocarbon generation from black shale, a process of which both the mechanisms and controls are little known.

\subsection{Metals in black shales from seafloor springs}

Black shales rich in organic matter are often also rich in chalcophilic metals, gold, and platinum group elements (PGE). Even in average black shales, metal levels often exceed crustal levels by $10^{5}-10^{6}$ times. Studies of Proterozoic, Ordovician, Devonian, Permian, Cretaceous-Tertiary and other black shales in the United States, Canada, the Baltic Shield, Siberia, and China (e.g., Granch \& Huyck, 1989; Wignall, 1994; Fedikow et al., 1998) suggest metal sources in the depositional environment: in anoxic or euxinic depositional environments chalcophilic $(\mathrm{Cu}, \mathrm{Co}, \mathrm{Zn}, \mathrm{Pb}, \mathrm{Cd}, \mathrm{Hg}, \mathrm{Ag}, \mathrm{As}, \mathrm{Ni})$ and precious metals (Au and PGE) may be incorporated in bottom sediments through precipitation of sulfides, whereas oxo-cations (Mo, Cr, U, V, Se) may be reduced and the elements scavenged from seawater by the fine particulate organic matter falling through the water column. Mass balance considerations indicate, however, that seawater alone does not explain element abundances even for the black shales of the Cretaceous-Tertiary boundary event (Brumsack, 2003), requiring other (fluvial and/or hydrothermal) inputs. For shale-hosted Ni-Zn-MoPGE deposits several genetic models have been suggested, reflecting the limited data available and the unusual presence of PGE without ultramafic rocks. Siliceous venting tubes and chert beds in the underlying beds in the Yukon suggest a hydrothermal source for metals (Lefebure \& Coveney, 1995); syngenetic deposition from seafloor springs with deposition of metals on or just below the seafloor is the most favored model. 


\section{Methodology}

If there is significant contribution from hydrating mantle peridotites to petroleum formation, it should be reflected in the trace element composition of petroleum. In the present study, we analyzed 24 trace elements by internally coupled plasma-mass spectrometry (ICP-MS) in 68 oils sampled in all seven producing sedimentary basins of Brazil and, for comparison, in 9 oils from major oil-producing areas outside Brazil. All analyses were made by one of us (Fonseca, 2000). We examined correlations between the individual trace elements, differences in trace element compositions among basins of different tectonic and sedimentary settings, and the effect of thermal cracking related to igneous activity. Studies of this kind, covering a wide range of trace metals in petroleum and their regional distribution over a large area, are still rare in the published literature.

We also studied correlations of trace element compositions of the oils with major geochemical earth reservoirs such as chondrite, fertile mantle, primitive mantle, continental crust, and seawater. Brazil is particularly favorable for testing the relationship between the oils and mantle peridotites because most of its oil deposits occur along the Atlantic margin, where early Cretaceous rifting between South America and Africa thinned the continental crust and partially unroofed the mantle lithosphere (Zalan et al., 2010).

\section{Geologic setting}

Petroleum is produced in Brazil in several basins along the South Atlantic continental margin and inland (Fig. 1).

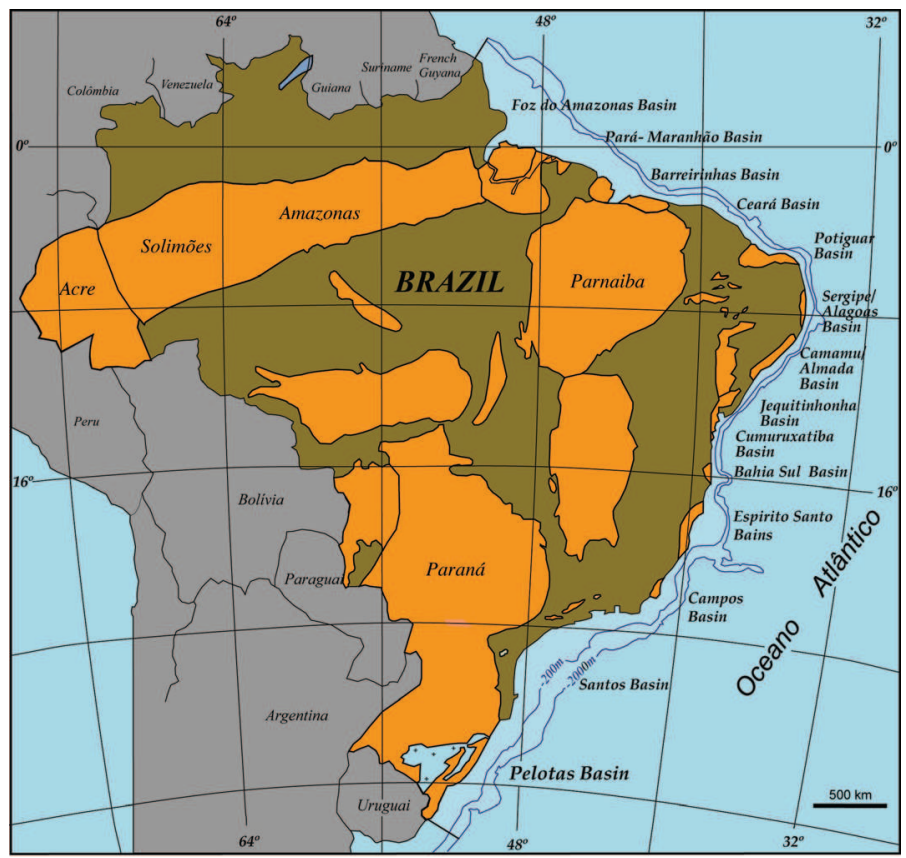

Fig. 1. Marginal basins of Brazil along the South Atlantic. 
Except for the Paleozoic Amazonas-Solimões Basin far inland, the oil-producing basins lie over rifted continental crust along or near the continental margin and formed during early Cretaceous continental breakup between South America and Africa. Production in 2009 exceeded 2 million barrels per day. Most of the oils are low in sulfur and vanadium; their biomarkers mostly derive from early Cretaceous syn-rift lacustrine (freshwater and saline) source rocks and from largely post-rift Aptian siliciclastic source rocks deposited in a marine hypersaline environment (Katz \& Mello, 2000). The geologic setting and organic geochemistry of Brazilian oils have been amply discussed in the published literature (e.g., Katz \& Mello, 2000; Schiefelbein et al., 2000; Milani \& Zalan, 1998; Cainelli \& Mohriak, 1998; Szatmari, 2000); here we provide only a short summary. The basins sampled (Fig. 1) include the Paleozoic Upper Amazon (Solimões) basin in Amazonas state far inland and six Cretaceous to Tertiary basins along the rifted South Atlantic margin: the Potiguar basin in Rio Grande do Norte state, the Sergipe-Alagoas basin in the homonymous states, the aborted Recôncavo rift in Bahia state, the Espírito Santo basin in Espírito Santo state, the Campos basin in Rio de Janeiro state, and the southern Santos basin. These basins are respectively referred to, in both the text and figures, by the abbreviations $a m, r n, s e, b a, e s, r j$, and $b s$. The pre-salt accumulations recently discovered in the Santos Basin are not discussed in this study. In addition, nine oil samples from outside Brazil, marked for (foreign), were taken from rich petroleum producing areas worldwide, with mostly marine source rocks. Brazil's oldest oil producer is the mostly onshore Recôncavo basin in Bahia state, NE Brazil, an aborted continental rift separated from the continental margin by the wide SalvadorJacuipe horst. The sedimentary sequence of the basin consists mostly of late Jurassic to early Cretaceous fluvial to lacustrine siliciclastic strata that contain both the reservoirs and the organic-rich source rocks. Igneous rocks, evaporites and marine sediments are absent. The oils are viscous but mostly free of biodegradation; their high viscosity is due to long-chain paraffins, attributed to lacustrine plant sources.

Also in NE Brazil, the oil of the Potiguar basin is sourced in part from the passive margin and in part from an aborted lacustrine rift inland. The Sergipe-Alagoas basin lies along the passive margin and contains thick marine evaporites. Reservoir rocks in both basins are mostly of Cretaceous age.

In SE Brazil, the partly offshore Espírito Santo and the wholly offshore Campos and Santos basins along the continental margin contain thick Aptian evaporites, underlain by thick sediments and early Cretaceous basalts related to the large continental flood basalts of the Paraná Basin. The reservoirs are mostly of Cretaceous and Tertiary age; biodegradation is often intense.

Light oils and condensates are produced in the offshore Cretaceous southern Santos and the Paleozoic inland Amazon-Solimões basins. In the latter basin the oil is thought to be sourced from Devonian shales and produced from Carboniferous sediments overlain by Carboniferous evaporites and intruded by Juro-Triassic diabase sills and dikes. Thermal cracking has been demonstrated by diamondoid studies (Dahl et al., 1999); asphaltene content is low or absent.

\section{Analytical method}

We have taken 68 oil samples from all oil-producing sedimentary basins in Brazil, over an area more than 3,000 km across (nearly 2,000 miles; Fig. 1). Nine additional samples were taken from major oil producing areas outside Brazil. Each sample was analyzed for 24 trace 
elements: Ti, V, Cr, Mn, Fe, Co, Ni, Cu, Zn, Ga, As, Rb, Sr, Y, Mo, Ag, Ba, La, Ce, Pr, Nd, W, $\mathrm{Pb}$, and $\mathrm{U}$, using a Perkin-Elmer-Sciex, Model Elan 5000, internally coupled plasma-mass spectrometer (ICP-MS). Of the 24 elements analyzed, 13 (Ti, V, Cr, Mn, Fe, Co, Ni, Cu, Zn, Y, $\mathrm{Mo}, \mathrm{Ag}, \mathrm{W}$ ) were transition metals; 4 ( $\mathrm{La}, \mathrm{Ce}, \mathrm{Pr}, \mathrm{Nd}$ ) were rare earth elements. Pr, $\mathrm{W}$, and $\mathrm{U}$, which were below the sensitivity limit of the method in nearly two thirds of the samples, were only partially evaluated. Sr was contributed in some samples in part by the residual brine retained in the oil samples, especially in viscous $b a$ oils.

Microwave digestion was used to prevent escape of volatile components; the isotopes to be measured were selected so as to minimize interference by isobaric ions and plasma gas ions of coincident mass (Filby \& Olsen, 1994).

\section{Results and discussion}

\subsection{Correlations between trace metals in the oils}

For each trace metal and metal ratio, frequency distributions, means and medians were calculated for individual basins and for the total dataset. Frequency distributions are close to lognormal. The geometric means are close to the medians (oilmed77 for the 77 oils) and to the mode whereas the arithmetic means are higher and more influenced by outliers (Fig 2).

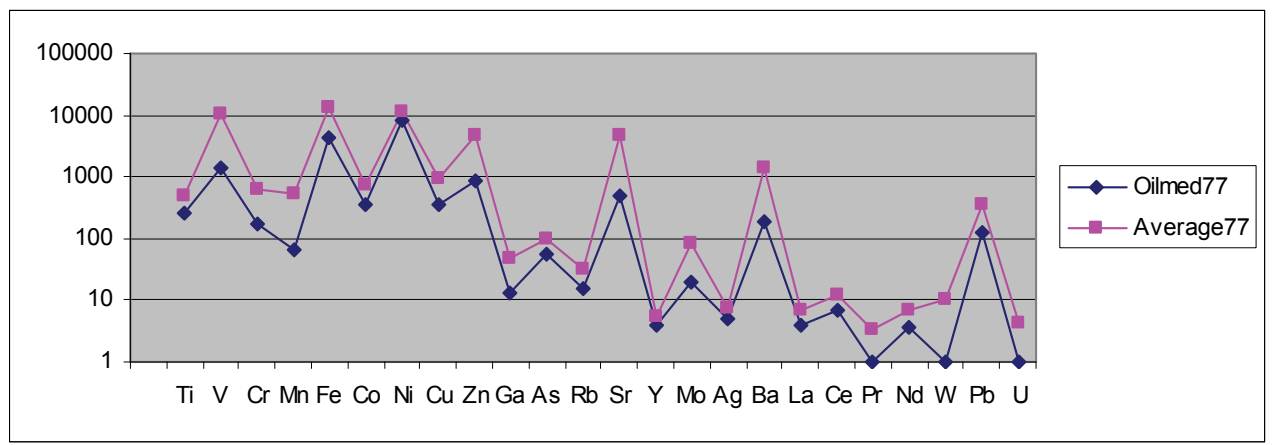

Fig. 2. Comparison of medians and arithmetic averages (means) of the 77 oils analyzed. The medians are better representations, less influenced by outliers, and close to the means of logarithms.

The medians of the oils, calculated for the individual basins and for the whole dataset, nearly coincide with the means of the logarithms of elemental abundances for which standard deviations were calculated. Median trace metal compositions for the 68 Brazilian and the 9 foreign oils are similar (Fig. 3) but the foreign oils tended to be higher in $\mathrm{V}$ and lower in Co and As.

Frequency distributions are closest to lognormal for As, Fe, Ce and, less clearly (perhaps because of their low concentrations) for $\mathrm{La}, \mathrm{Nd}, \mathrm{Y}, \mathrm{Mo}$, and $\mathrm{Ga}$. Frequencies are skewed from lognormal toward smaller values for $\mathrm{Sr}, \mathrm{Ba}, \mathrm{Rb}, \mathrm{Mn}, \mathrm{Cu}$, and $\mathrm{Pb}$ and to a lesser extent also for $\mathrm{Cr}$ and $\mathrm{Ti}$. $\mathrm{Zn}$ and $\mathrm{Ag}$ are more irregular; their frequency distributions are flatter. Relative to lognormal, the distributions are skewed toward higher values for $\mathrm{Ni}$ and $\mathrm{Co}$, and less regularly for $\mathrm{V}$, elements most characteristic of asphaltenes. 


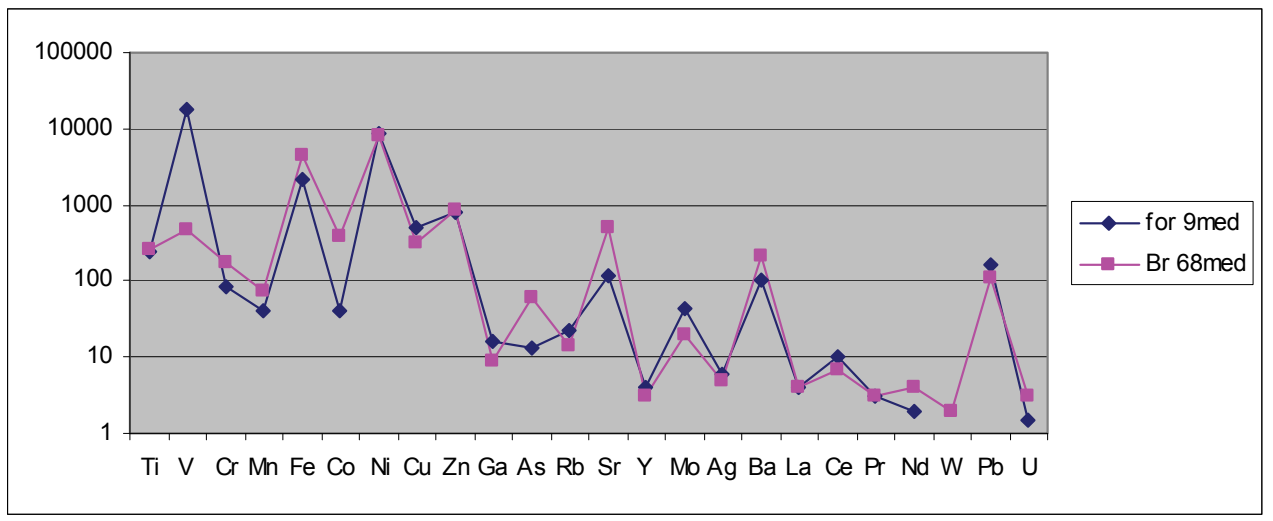

Fig. 3. Comparison of median trace element distributions (ppb) of 68 Brazilian and of 9 foreign oils. Note great similarity, with higher V and lower Co and As in the foreign oils.

Standard statistical methods including cluster analysis were used to measure correlations between elements. Logarithms were preferred for correlation because of the lognormal distribution of the elements. Log-log correlations in the 68 Brazilian oils are best $\left(\mathrm{r}^{2}>0.85\right)$ for the La-Ce and Pr-Nd couples; very good ( $\left.\mathrm{r}^{2}>0.7\right)$ for the Co-Ni, Ce-Nd, and Sr-Ba couples; and less good $\left(\mathrm{r}^{2}>0.55\right)$ for the $\mathrm{V}-\mathrm{Ni}, \mathrm{Ga}-\mathrm{Mo}$, and $\mathrm{Mn}-\mathrm{Fe}$ couples.

\subsection{Trace element groups}

We compared trace element abundances and ratios in the oils with major geochemical reservoirs: CI carbonaceous chondrite (Anders \& Grevesse, 1989), serpentinized fertile upper mantle peridotite from the Vosges Mts, France (UB-N geostandard, Govindaraju, 1982, 1995; Meisel et al., 2003), primitive mantle (McDonough \& Sun, 1995), oceanic (" $8 \%$ MgO" MORB) and continental crust (Rudnick \& Fountain, 1995; Wedepohl, 1995), and seawater (Broeker \& Peng, 1982; Quinby-Hunt \& Turekian, 1983), extensively using the home page of the Geochemical Earth Reference Model (GERM).

Below we shall briefly review the regional distribution of each trace element group, using their median values in each basin. The basins are indicated by abbreviations: $r n$ (mainly Potiguar Basin in Rio Grande do Norte state), se (Sergipe), ba (Recôncavo Basin in Bahia state), es (Espírito Santo) , rj (Campos Basin in offshore Rio de Janeiro), bs (southern, post-salt part of the Santos Basin), and am (the inland Amazonas-Solimões basin). For designates the 9 foreign oils we analyzed for comparison, from Saudi Arabia, Iran and Yemen in the Middle East; Peru, Venezuela, Ecuador and Mexico in the Americas, and one from the Niger Delta.

We distinguished four groups of trace elements, without rigid limits among the groups:

Mantle-derived elements, Group 1: Co, Ni, Ga, (Cu, Zn), La, Ce, Nd

Mantle-derived elements, Group 2: $\mathrm{Cr}, \mathrm{Mn}, \mathrm{Fe}$, (Ti)

$\mathrm{V}$, Mo

Elements enriched in hydrothermal brines: $(\mathrm{Cu}, \mathrm{Zn}, \mathrm{Mo}), \mathrm{As}, \mathrm{Ag}, \mathrm{Pb}$

Mantle-derived elements Group I : Ni, Co, Ga, (Cu, Zn), La, Ce, Nd

The oils contain about 10,000 ppb for $\mathrm{Ni}$ in most of the Brazilian and foreign oils we analyzed. In the thermally cracked light am oils of the Amazon-Solimões basin, affected by 
Juro-Triasssic subvolcanic and hydrothermal activity, Ni is reduced to below 1000 and often below $100 \mathrm{ppb}$. Co is 1000 to $100 \mathrm{ppb}$ in most oils; but only 1-5 ppm in most thermally cracked, light am oils.

$\mathrm{Ga} / \mathrm{Ni}$ vs. Ce/Ni ratios (Fig.4) and the Ga/Ni vs. Co/Ni ratios (Fig. 5) plot close to mantle (M) and chondrite $(\mathrm{CH})$ values; the distributions of $\mathrm{La}$ and $\mathrm{Nd}$ are similar to $\mathrm{Ce} . \mathrm{Co} / \mathrm{Ni}$, $\mathrm{Ga} / \mathrm{Ni}$, and $\mathrm{Ce} / \mathrm{Ni}$ ratios show little differentiation between the oils of the various basins. The $b a$ oils have the lowest $\mathrm{Ga} / \mathrm{Ni}$ ratios. The high $\mathrm{Ce} / \mathrm{Ni}$ and $\mathrm{Ga} / \mathrm{Ni}$ ratios of the am oils reflect the lowered Ni content of these thermally cracked low-asphaltene oils.

$\mathrm{Cu} / \mathrm{Ni}$ and $\mathrm{Zn} / \mathrm{Ni}$ also plot close to mantle and chondrite, but they are modified by hydrothermal processes, with a partial shift toward crustal and seawater values (Fig. 6).

Mantle- derived elements Group II : $\mathrm{Cr}, \mathrm{Mn}, \mathrm{Fe}$, (Ti)

The abundances of these elements in the various basins are similar; irregularities of the curves show relatively minor local variations. Fe is a few $1000 \mathrm{ppb}, \mathrm{Ti}$ and $\mathrm{Cr}$ are a few 100 ppb; Mn is mostly below $100 \mathrm{ppb}$.

Compared to chondritic or mantle values, $\mathrm{Mn}, \mathrm{Fe}$ and $\mathrm{Cr}$ are very low in the oils, but their ratios are close to mantle $(\mathrm{M})$ and chondrite $(\mathrm{CH})$ values, except for the $b a$ oils and the thermally cracked am oils (Fig. 7).

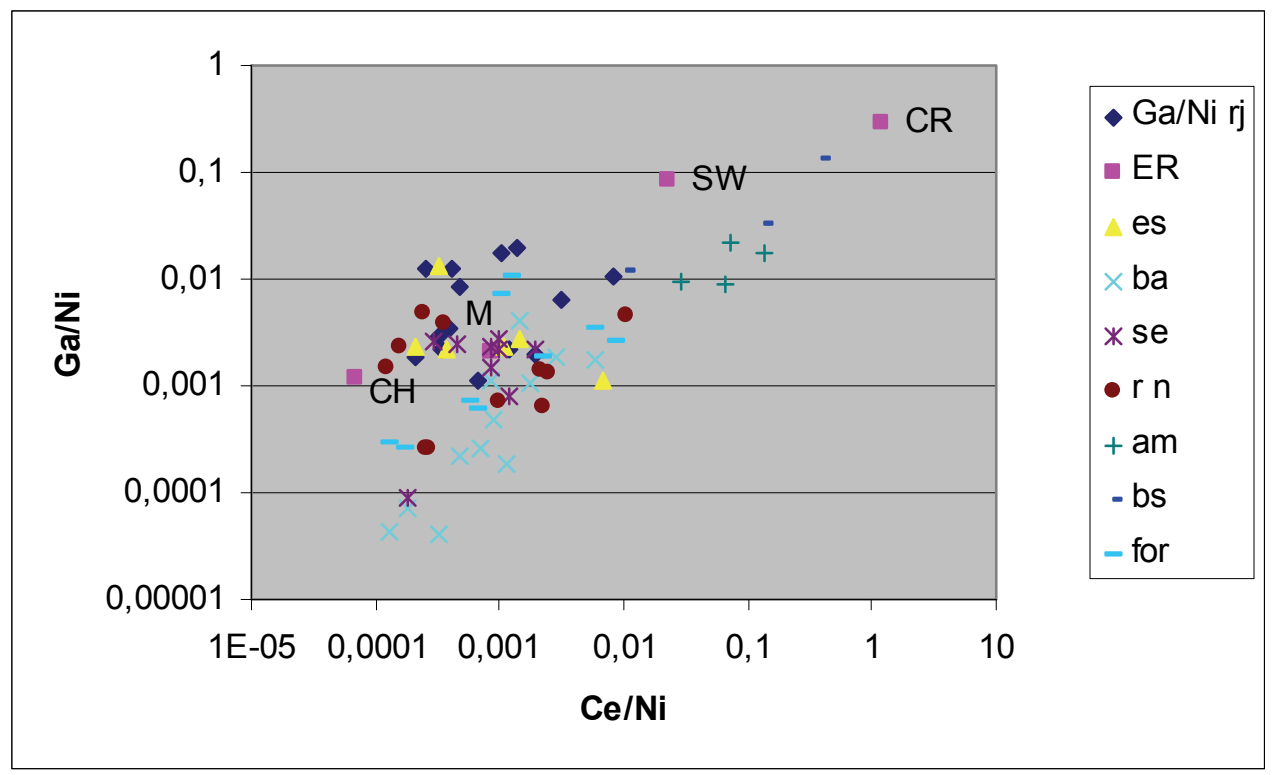

Fig. 4. Ga/Ni versus Ce/Ni ratios in 68 Brazilian and 9 foreign oils. Note clustering around mantle and chondrite values. ER - reservoir data from the Geochemical Earth Reference Model (GERM): CH - CI chondrite; M - mantle; CR - continental crust; SW - seawater. Brazilian basins: rj - Campos (Rio de Janeiro); es - Espírito Santo; ba - Recôncavo (Bahia); se - Sergipe-Alagoas; rn - Potiguar (Rio Grande do Norte); am - Amazonas-Solimões; bs southern Santos (post-salt); for - foreign samples. 


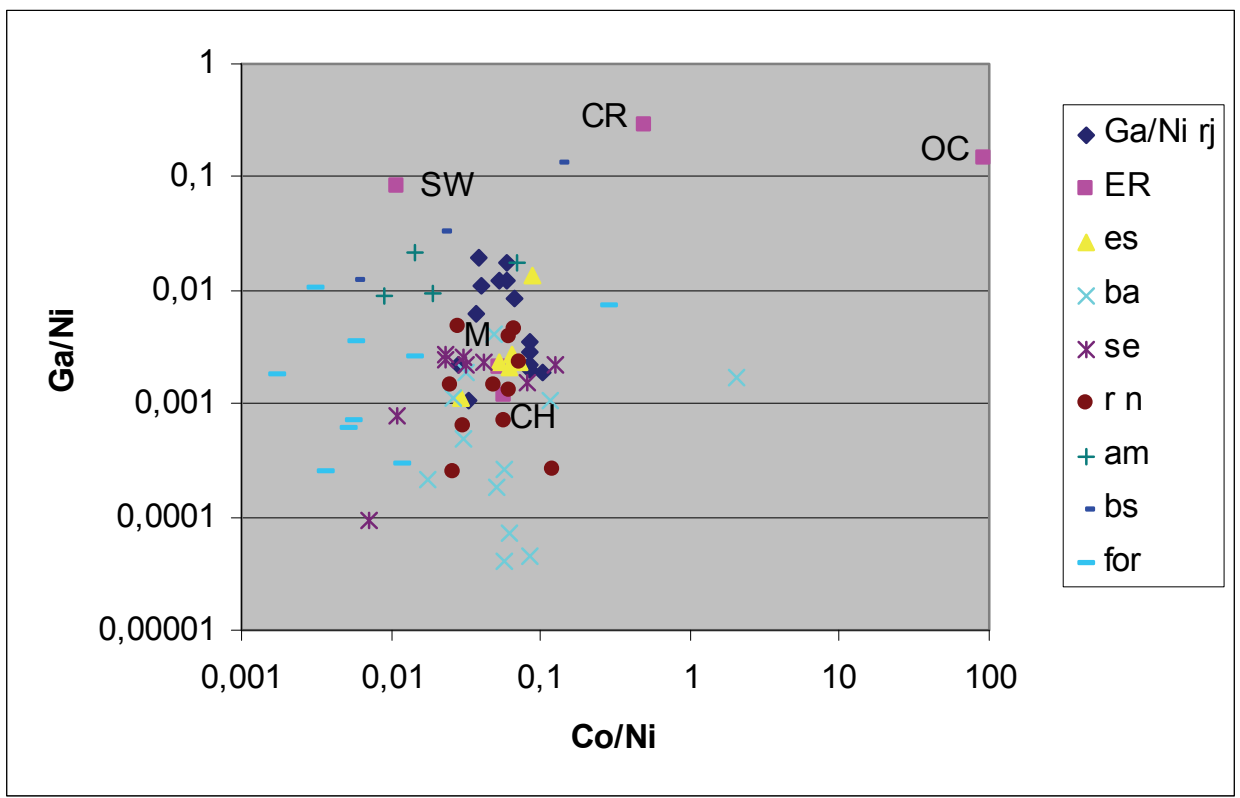

Fig. 5. Ga/Ni versus $\mathrm{Co} / \mathrm{Ni}$ ratios in 68 Brazilian and 9 foreign oils. Note clustering around mantle and chondrite values. Abbreviations as above; OC - oceanic crust added.

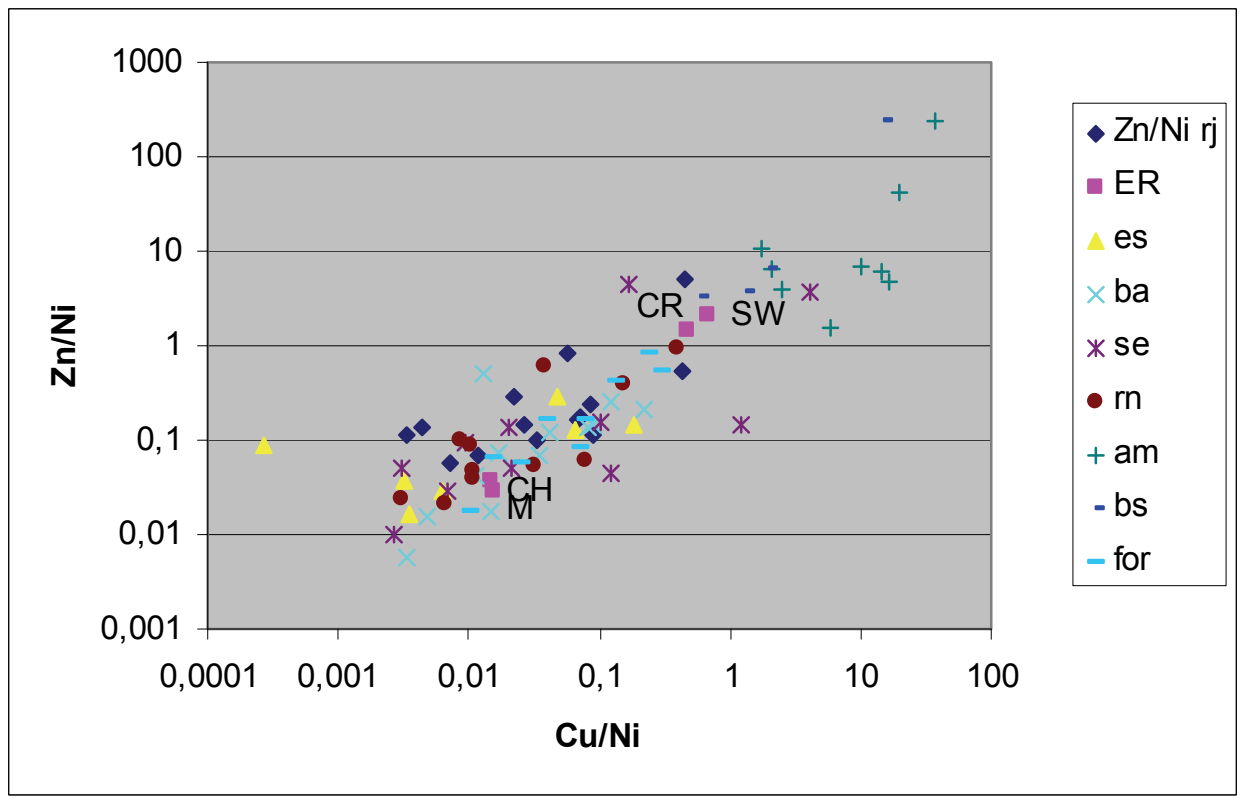

Fig. 6. Zn/Ni vs. Cu/Ni ratios plot dominantly close to the nearly identical chondrite and mantle values, but a large part of them plots close to continental crust and seawater (even beyond in the thermally cracked am oils) reflecting their mobility in hydrothermal brines. 


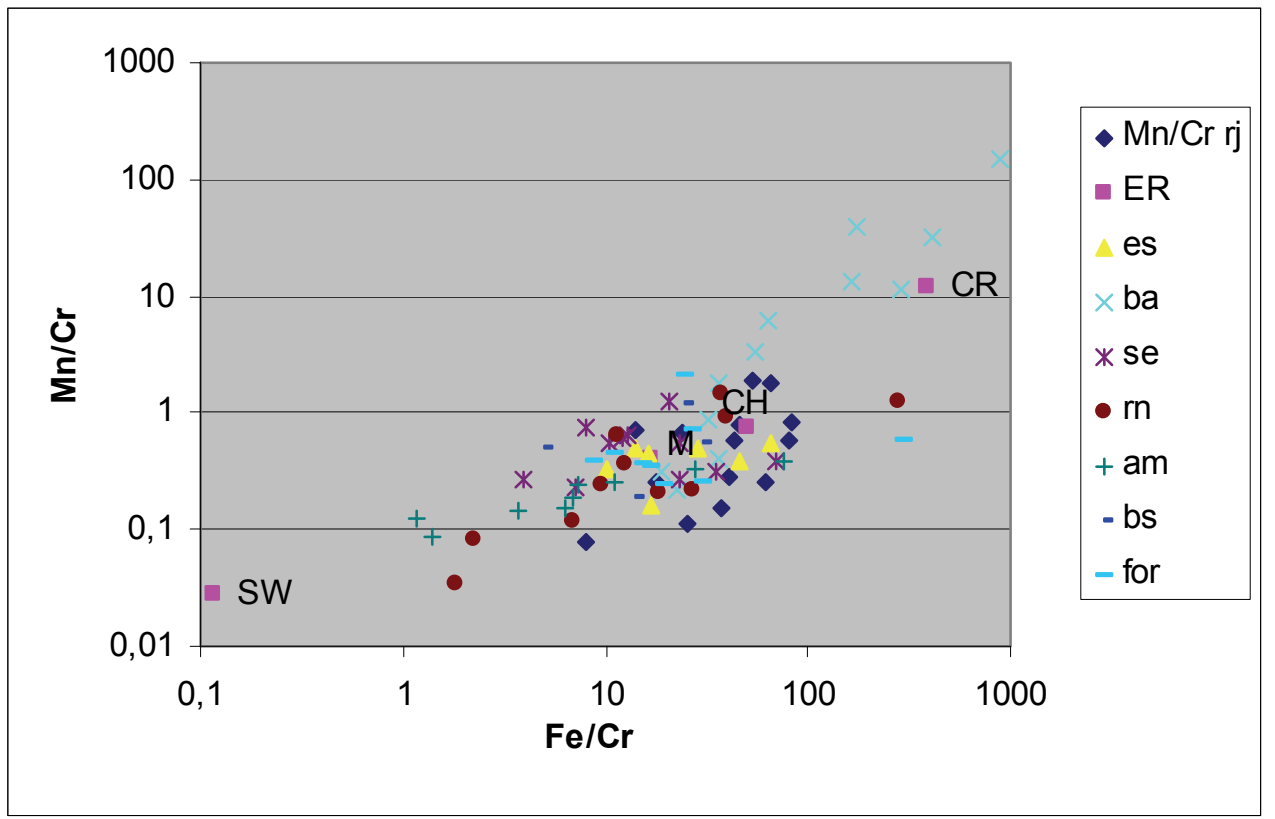

Fig. 7. Mn/Cr versus Fe/Cr in 68 Brazilian and 9 foreign oils. Note clustering around mantle and chondrite values.

\section{V, Mo}

$\mathrm{V}$ varies more widely in the Brazilian oils than any of the other elements, it shows the greatest variation between basins and sometimes even between individual samples. Mo also varies widely, ranging from a few ppb to nearly $1000 \mathrm{ppb}$. The dispersion of $\mathrm{V}$ in our dataset, defined as the ratio of the third and first quartiles, is more than 100, compared with 27 for Co and 14 or less for all other elements, including Ni. V is above 10,000 ppb in the $r j$ and above 100,000 ppb in the for oils, but below $1000 \mathrm{ppb}$ in the $b a$ oils and mostly below 25 $\mathrm{ppb}$ in the thermally cracked am oils in which asphaltenes are nearly absent. As a result, $\mathrm{V} / \mathrm{Co}$ vs. $\mathrm{V} / \mathrm{Ni}$ ratios plot along the whole range from chondritic to seawater values (although this last one only in foreign oils) (Fig. 8).

$\mathrm{V} / \mathrm{Ni}$ ratios (Fig. 8) are very low, chondritic to mantle-like (close to 0,01), in the $b a$ oils of the aborted Recôncavo rift and only slightly higher (0.04) in some of the $r n$ oils from the aborted rift of the Potiguar basin. They rise somewhat above mantle values (0.1-1) in the se, es and the rest of the $r n$ oils of the Sergipe-Alagoas, Espírito Santo and Potiguar basins, and reach levels close to crustal values (1-2) in most of the rj oils in SE Brazil. Still higher levels (2-10), ranging from crustal to seawater values, were measured in various marine-sourced for oils we analyzed from Venezuela, Ecuador, Peru, Mexico, Iran, and Yemen.

Similarly, V/Co ratios are very low, chondritic to mantle-like (0.1 to 1$)$, in the V-poor oils of the fresh-water rift sequences of the aborted rifts of the Reconcavo $(b a)$ and Potiguar basins, and vary from mantle to crustal values (1-10) in most oils along the continental margin, reaching higher levels (10 to 100) in the $r j$ oils of SE Brazil. Even higher ratios (100 to 2000), close to seawater values,were found in various marine-sourced for oils from outside Brazil 
(Venezuela, Ecuador, Peru, Mexico, Iran, and Yemen). V/Co ratios vs. V/Ni ratios lie along a chondrite-seawater mixing line (Fig. 8). The highest V/Co ratios reflect the sharp drop of Co abundances and $\mathrm{Co} / \mathrm{Ni}$ ratios in high-V (>100,000 ppb) non-Brazilian oils, such as the for oils of our dataset and Curiale's (1987) heavy oils.

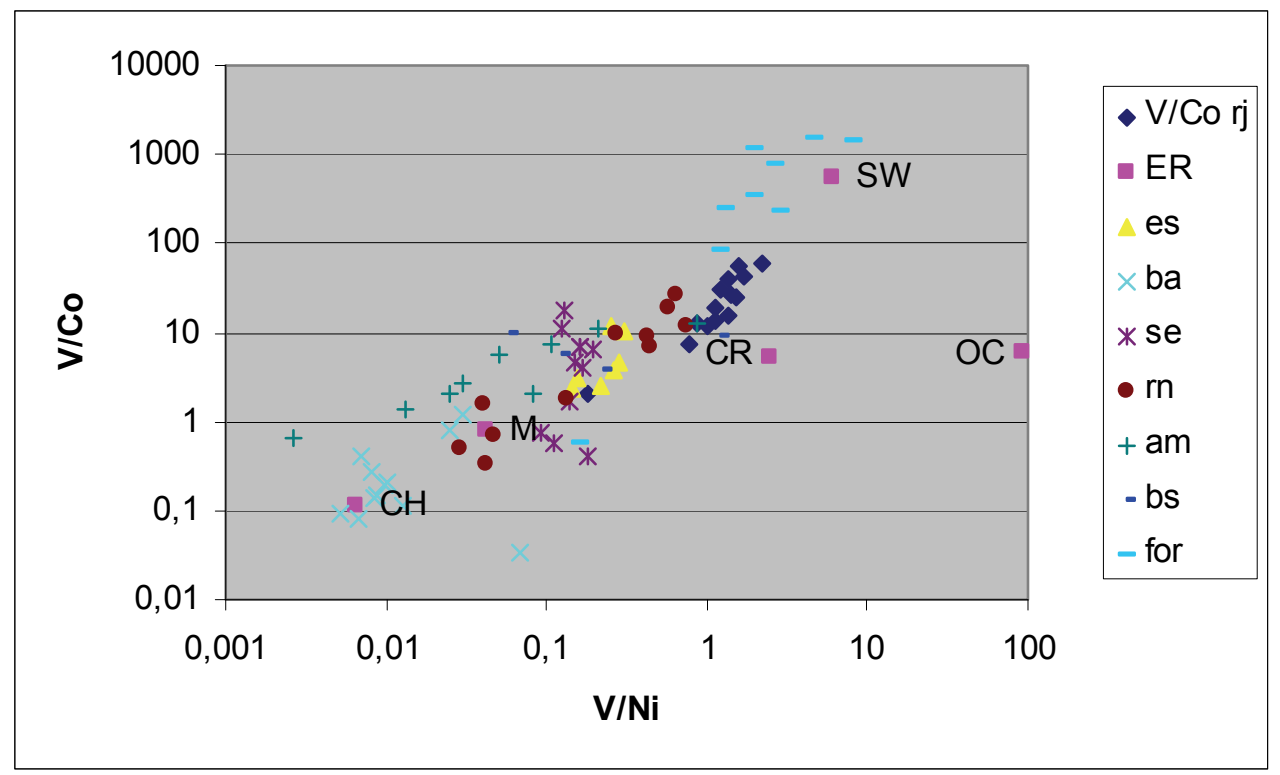

Fig. 8. V/Co versus V/Ni ratios in 68 Brazilian and 9 foreign oils. Note the wide range of distribution between the medians of the various basins, ranging from chondritic to seawater values. Abbreviations as above.

Differently from the wide range of distributions of V/Co vs. V/Ni (Fig. 8), V/Mo vs. Co/Ni values (Fig. 9) are close to the chondrite to mantle range (except for the cracked am oils), suggesting that $\mathrm{V}$ and Mo both derived from the mantle and were modified by similar processes after leaving their mantle source.

\section{Elements enriched in hydrothermal brines: (Cu, $\mathrm{Zn}, \mathrm{Mo}), \mathrm{As}, \mathrm{Ag}, \mathrm{Pb}$}

As shown above, most of the $\mathrm{Cu} / \mathrm{Ni}$ vs. $\mathrm{Zn} / \mathrm{Ni}$ ratios plot near mantle and chondrite, but a long tail to crustal and seawater values testifies their hydrothermal mobility (Fig. 6).

In the thermally cracked light am oils of the Amazon-Solimões basin, affected by JuroTriasssic subvolcanic and hydrothermal activity, $\mathrm{Cu}$ rises five times, $\mathrm{Zn}$ and $\mathrm{Pb}$ two times above the median of Brazilian oils. $\mathrm{Zn}$ is highest, close to $1000 \mathrm{ppb}, \mathrm{Cu}$ about $300 \mathrm{ppb}, \mathrm{Pb}$ about $100 \mathrm{ppb}$, and Ag below $10 \mathrm{ppb}$. Variations between the other basins are small, less than an order of magnitude.

In the am oils, Ni-normalized ratios of these elements are higher than crustal values, mainly owing to the loss of $\mathrm{Ni}$ from the thermally cracked oils, but also because of the higher levels of $\mathrm{Cu}, \mathrm{Zn}$, and $\mathrm{Pb}$ in this basin intruded by thick diabase sills.

Reflecting the greater hydrothermal mobility of Mo, Mo/Ni ratios move away from the mantle-chondrite area. Mo/ Ni is lower in the V-poor ba oils of the Recôncavo rift (Fig.10). 


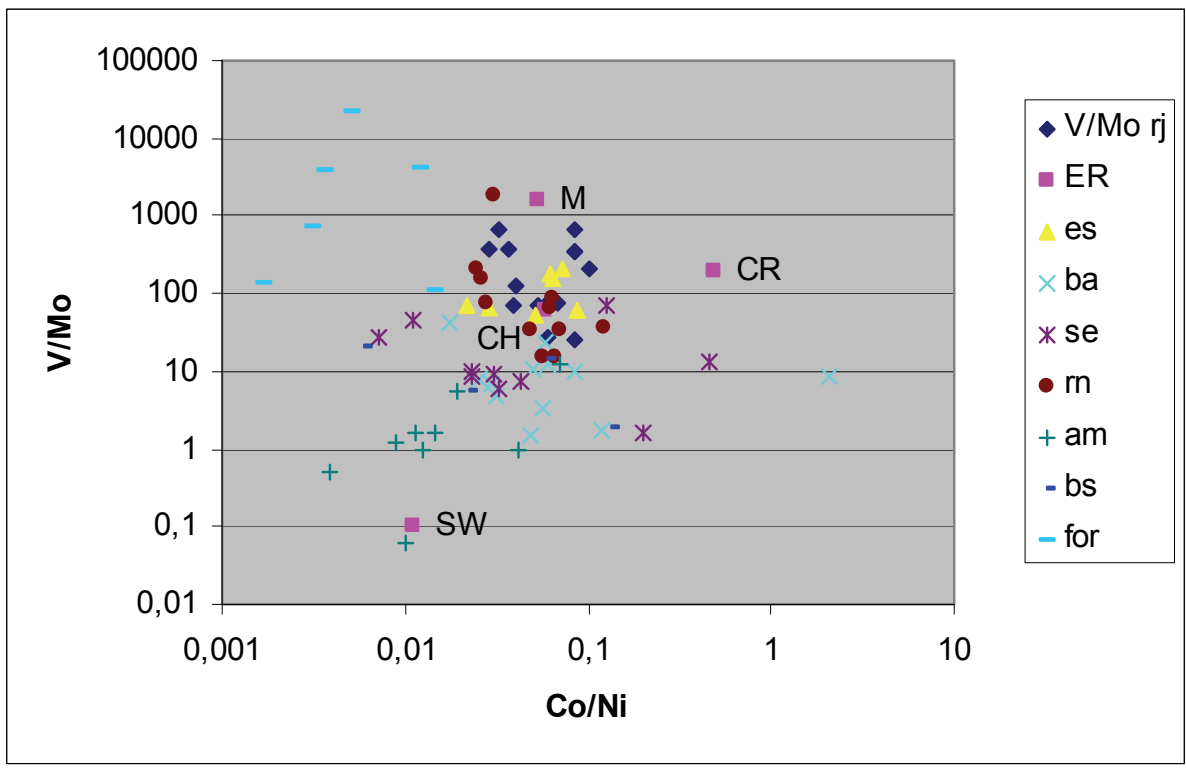

Fig. 9. V/Mo versus Co/Ni ratios in 68 Brazilian and 9 foreign oils. Note clustering around mantle and chondrite values. Abbreviations as above.

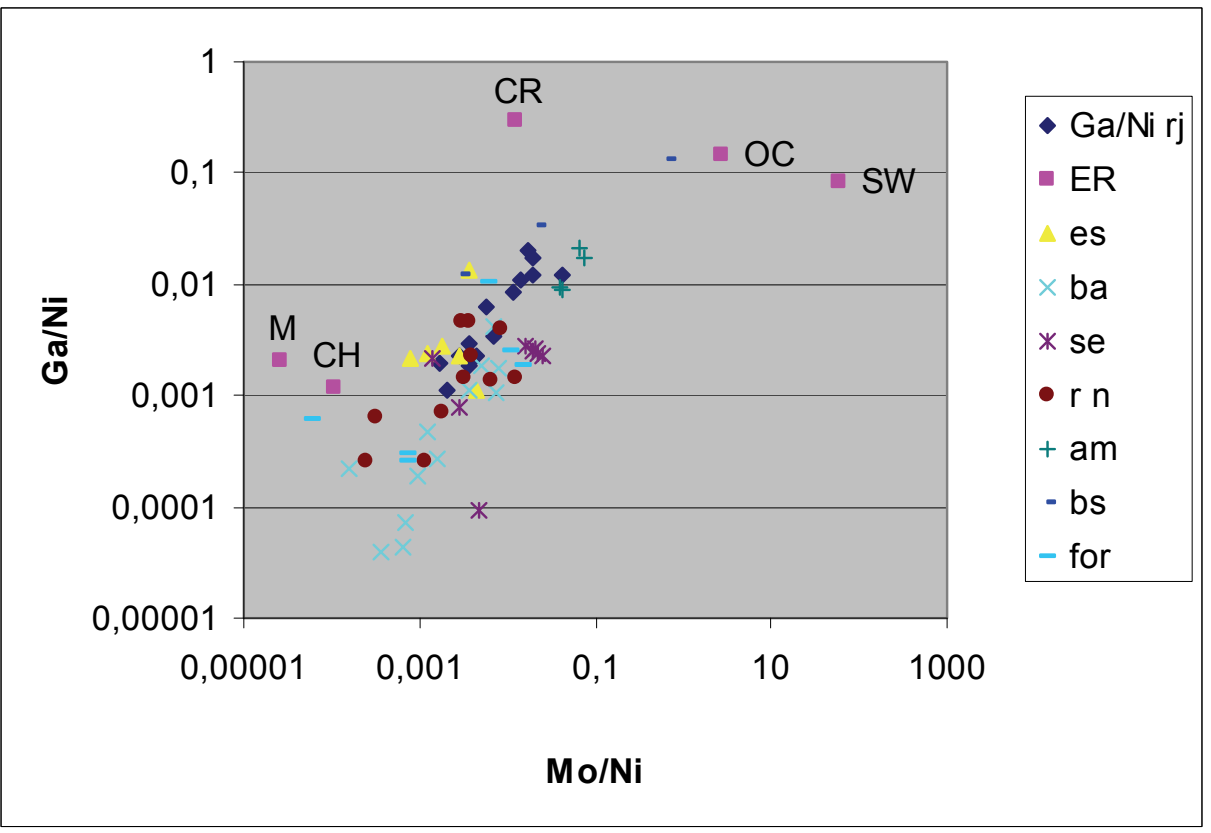

Fig. 10. Ga/Ni versus Mo/Ni ratios in 68 Brazilian and 9 foreign oils. Note clustering away from mantle and chondrite values, reflecting the hydrothermal mobility of Mo. Abbreviations as above. 


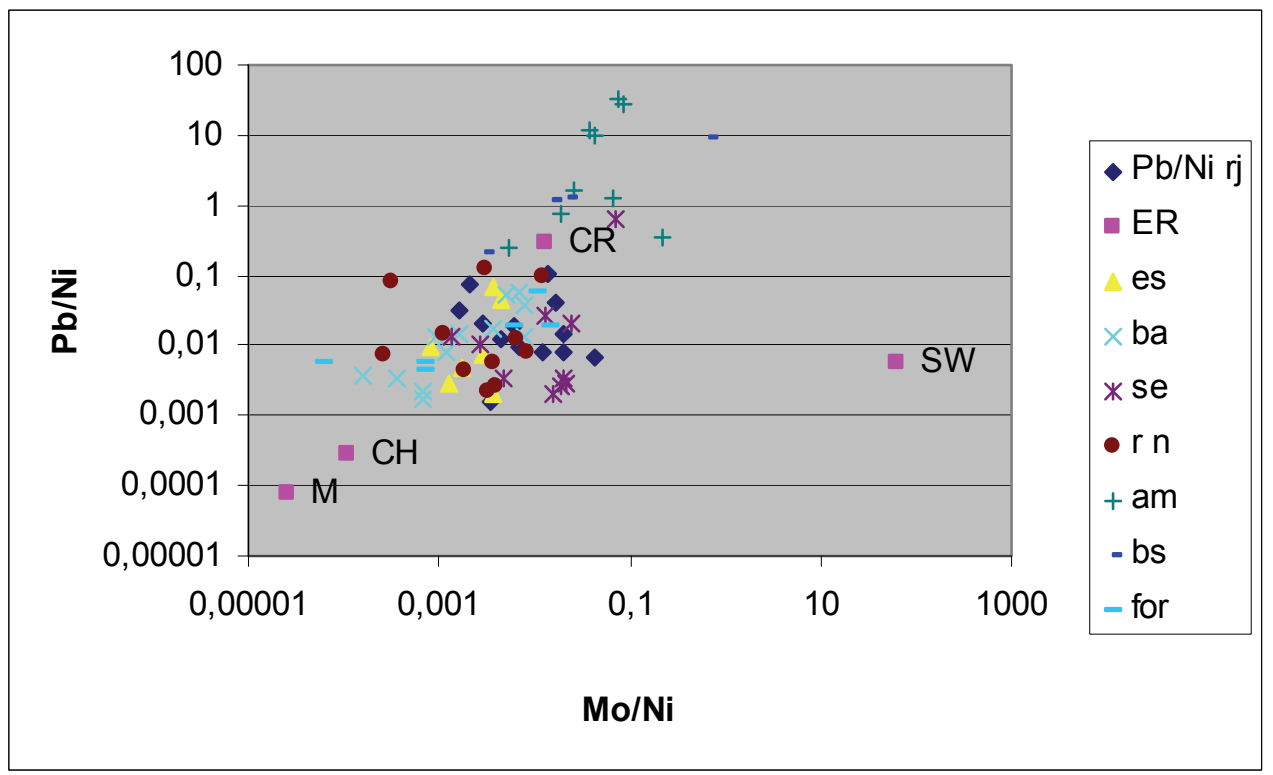

Fig. 11. $\mathrm{Pb} / \mathrm{Ni}$ versus $\mathrm{Mo} / \mathrm{Ni}$ ratios in 68 Brazilian and 9 foreign oils. Note clustering away from mantle and chondrite values, close to crustal ones, reflecting the hydrothermal mobility of both $\mathrm{Pb}$ and Mo. Abbreviations as above.

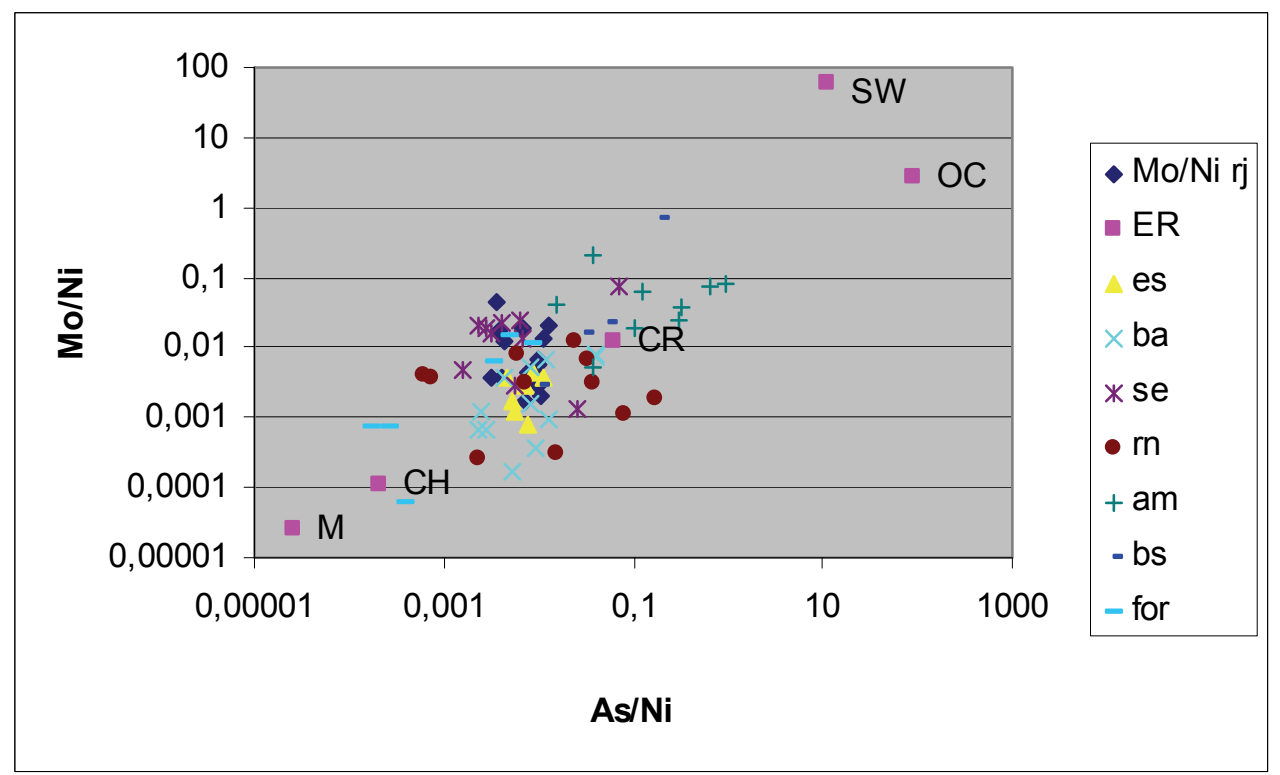

Fig. 12. Mo/Ni versus As/Ni ratios in 68 oils grouped by 7 Brazilian basins and 9 foreign oils. Note clustering away from mantle and chondrite, moving close to crustal values, reflecting the hydrothermal mobility of both As and Mo. Abbreviations as above. 
The shift to near-crustal values is conspicuous also for $\mathrm{Pb} / \mathrm{Ni}$ vs. $\mathrm{Mo} / \mathrm{Ni}$ ratios (Fig.11) and for $\mathrm{Mo} / \mathrm{Ni}$ vs. As/ $\mathrm{Ni}$ ratios (Fig. 12). As/ $\mathrm{Ni}$ and $\mathrm{Mo} / \mathrm{Ni}$ ratios are correlated and range from chondritic-serpentinitic to crustal values (and even higher in the am oils that have low Ni content). As/Ni ratios in the various basins are similar.

\section{Correlations with geochemical Earth reservoirs}

We found that log-log correlations of the median composition of the 24 trace elements in the Brazilian oils ( $\mathrm{Sr}$ is contained in residual brines in some of the oils) are very good with $\mathrm{CI}$ chondrite $\left(\mathrm{r}^{2}=0.80\right)$ and serpentinized fertile mantle $\left(\mathrm{r}^{2}=0.79\right)$; good with the primitive mantle $\left(\mathrm{r}^{2}=0.61\right)$; worse with oceanic $\left(\mathrm{r}^{2}=0.41\right)$ and continental crust $\left(\mathrm{r}^{2}=0.36\right)$; and none with seawater $\left(r^{2}=0.02\right)$. Log-log correlations of the median of the nine non-Brazilian oils (taken from major oil producing areas in the Middle East, Mexico, Venezuela, Ecuador, Peru, Angola, and the Niger Delta) are good with chondrite $\left(\mathrm{r}^{2}=0.62\right)$, serpentinized fertile mantle $\left(\mathrm{r}^{2}=0.63\right)$, and the primitive mantle $\left(\mathrm{r}^{2}=0.51\right)$; worse with oceanic $\left(\mathrm{r}^{2}=0.39\right)$ and continental crust $\left(\mathrm{r}^{2}=0.33\right)$; and none with seawater $\left(\mathrm{r}^{2}=0.04\right)$. The somewhat lower correlations for the non-Brazilian oils result from their much higher $\mathrm{V}$ and lower Co content. All these correlations are robust and change little when considering smaller sample groups or individual oils instead of the median of the entire dataset, nor are they significantly altered by removing any single element.

Table 1 compares some trace element ratios in the oils with the primitive mantle and the continental crust, showing their similarity to the former and dissimilarity to the latter.

$\begin{array}{lllllll}\begin{array}{l}\text { Metal } \\ \text { Ratios }\end{array} & \begin{array}{l}\text { Primitive } \\ \text { mantle }\end{array} & \begin{array}{l}\text { Oil } \\ \text { median }\end{array} & \begin{array}{l}\text { Oil geometric Cont. } \\ \text { mean }\end{array} & \begin{array}{l}\text { Oil 1 } \\ \text { crust }\end{array} & \begin{array}{l}\text { Oil } 3^{\text {rd }} \\ \text { quart. quart. }\end{array} \\ \mathrm{Fe} / \mathrm{Cr} & 23.8 & 23.9 & 23.20 & 388.2 & 10.8 & 45.7 \\ \mathrm{Mn} / \mathrm{Cr} & 0.40 & 0.43 & 0.55 & 11,76 & 0.24 & 0.80 \\ \mathrm{Co} / \mathrm{Ni} & 0.054 & 0.049 & 0.044 & 0.49 & 0.026 & 0.070 \\ \mathrm{Ga} / \mathrm{Ni} & 0.0020 & 0.0021 & 0.0021 & 0.29 & 0.00110 .055 \\ \mathrm{Cu} / \mathrm{Ni} & 0.015 & 0.052 & 0.077 & 0.47 & 0.0110 .40 \\ \mathrm{Cu} / \mathrm{Ni} & 0.015 & 0.027 & 0.028 & 0.47 & 0.0079 & 0.088 \\ \mathrm{~V} / \mathrm{Ni} & 0.042 & 0.158 & 0.155 & 2.51 & 0.04170 .591 \\ \mathrm{Ni} / \mathrm{Ce} & 1170.1 & 994.9 & 613.3 & 0.85 & 282.92710 .8\end{array}$

Table 1. Comparison of some trace element ratios in the 68 Brazilian oil samples with the primitive mantle (McDonough \& Sun, 1995), and the continental crust (Rudnick \& Fountain, 1995; Wedepohl, 1995). Note excellent correlation with the primitive mantle. $\left(\mathrm{Cu} / \mathrm{Ni}^{*}\right.$ : omitting basins in which the oil was thermally cracked).

Thus the median composition of trace elements analyzed in 68 Brazilian oils correlates poorly with continental or oceanic crust and not at all with seawater (Fig. 13).

In contrast, correlations with CI chondrite (Fig. 14) and with the mantle are good. The mantle that is not serpentinized (spinel peridotite, primitive and depleted mantles) differs from the oil in the absence of hydrothermally enriched elements $\mathrm{As}, \mathrm{Mo}, \mathrm{Ag}, \mathrm{Pb}$, whereas chondrite and serpentinized fertile mantle UB-N, like the oils, are enriched in these elements (Fig. 15-17). 


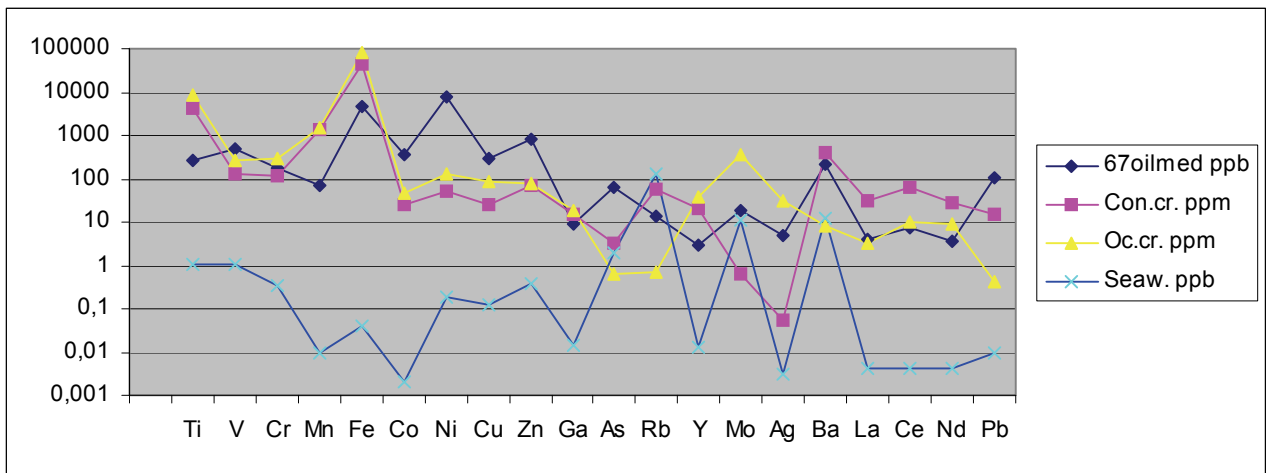

Fig. 13. Comparison of the median of 67 Brazilian oils with continental and oceanic crust and seawater. Correlations are poor with the crusts; there is no correlation with seawater.

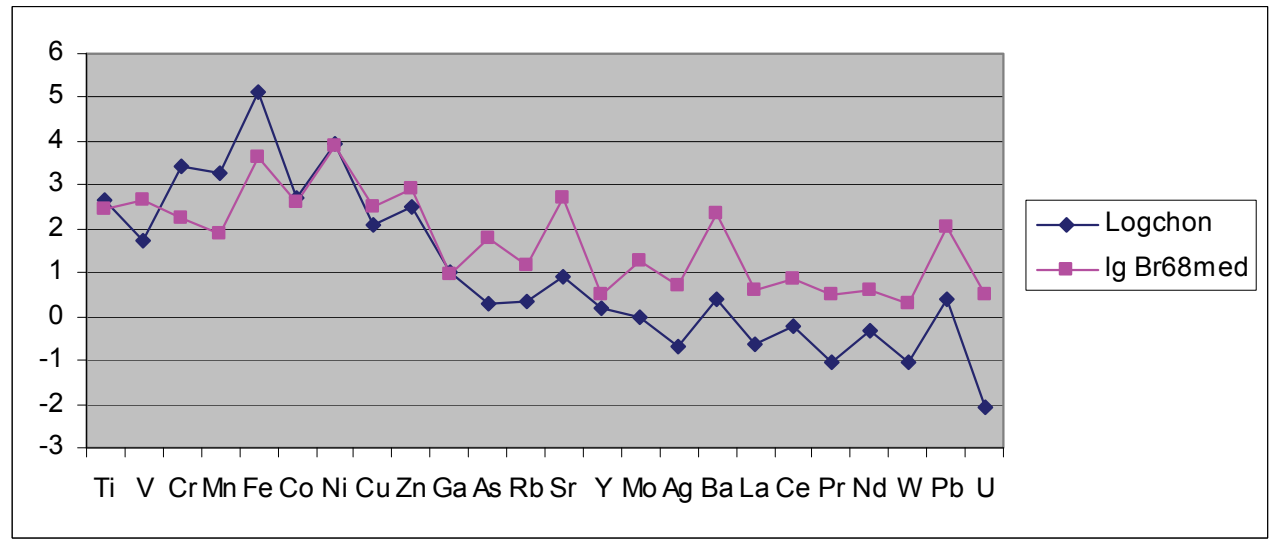

Fig. 14. Median composition of 68 Brazilian oils compared to chondrite.

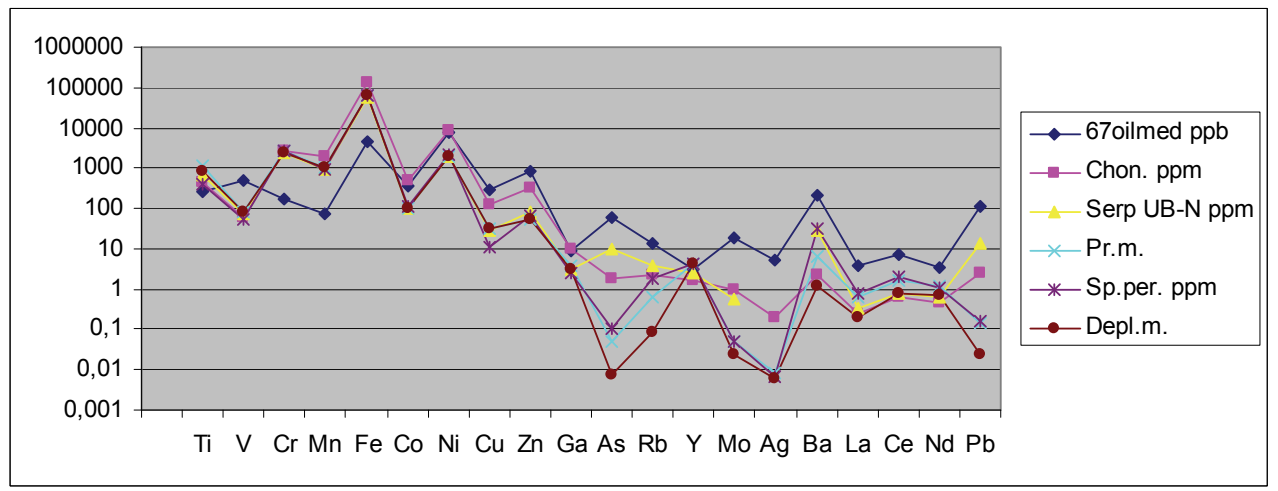

Fig. 15. Comparison of trace element medians of 67 Brazilian oils (ppb) with chondrite, serpentinized mantle UB-N, primitive mantle, spinel peridotite mantle and depleted mantle (ppm). Correlations are good, best with serpentinized mantle. 


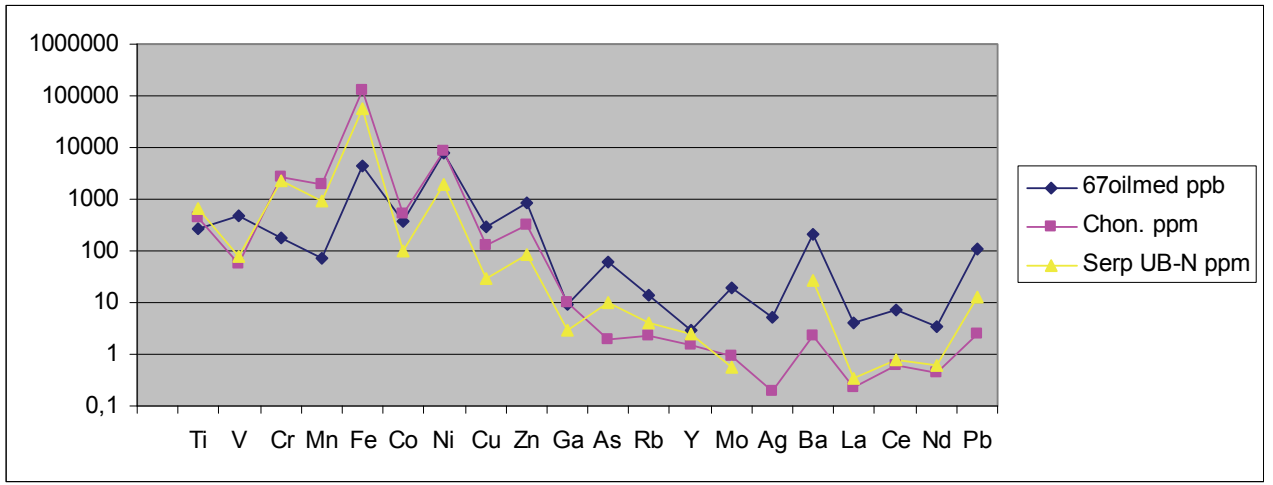

Fig. 16. Comparison of median trace element composition of the 67 Brazilian oils with chondrite and with serpentinized fertile mantle UN-B. Note the excellent correlations; the serpentinized mantle parallels more closely the hydrothermal enrichment of $\mathrm{As}$, and $\mathrm{Pb}$ in the oils.

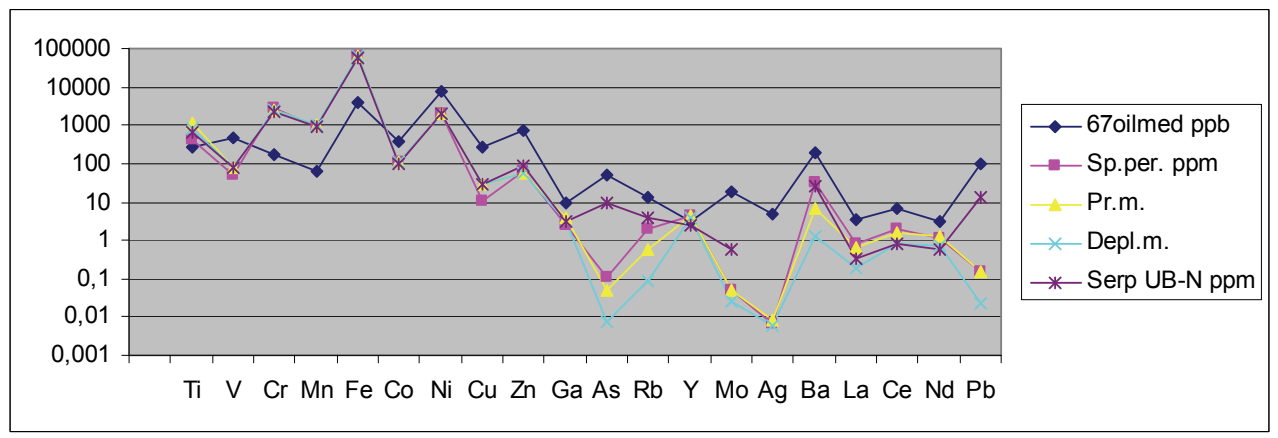

Fig. 17. Good correlation of the medians of 67 Brazilian oils (ppb) with four types of mantle (ppm): spinel peridotite mantle, primitive mantle, depleted mantle and serpentinized fertile spinel-peridotite mantle (UB-N). High relative abundances of hydrothermally enriched elements $\mathrm{As}, \mathrm{Mo}, \mathrm{Pb}$ are enriched only in the oils and in the serpentinized mantle.

\subsection{Correlations of trace element compositions with mantle peridotite}

Normalizing the medians of the Brazilian oils to chondrite and to spinel peridotite mantle, element abundances form indistinct plateaus (Fig. 18).

When we normalize the oil medians of the individual basins to spinel peridotite mantle/1000, these plateaus become more distinct (Fig. 19). Three groups of elements can be distinguished:

1. Mantle-derived elements Group 1 and $\mathrm{V}: \mathrm{Co}, \mathrm{Ni}, \mathrm{Ga},(\mathrm{Cu}, \mathrm{Zn}), \mathrm{La}, \mathrm{Ce}, \mathrm{Nd}$ are mostly close to $10 . \mathrm{Cu}$ and $\mathrm{Zn}$ are somewhat higher, reflecting hydrothermal enrichment; V varies highly (from 0.2 to 40 ) between the individual basins.

2. Mantle-derived elements Group 2: $\mathrm{Fe}, \mathrm{Cr}$, and $\mathrm{Mn}$ are two orders of magnitude lower, (0.02-0.07) but their ratios are mantle-like reflecting their retention in secondary magnetite and related spinels formed during serpentinization. $\mathrm{Fe} / \mathrm{Cr}$ and $\mathrm{Mn} / \mathrm{Cr}$ ratios 
are the same as in the mantle, $\mathrm{Ti} / \mathrm{Cr}$ is somewhat higher. $\mathrm{Fe} / \mathrm{Cr}$ and $\mathrm{Mn} / \mathrm{Cr}$ ratios in our oils plot about chondritic and mantle values (Table 1), as do to the average $\mathrm{Fe} / \mathrm{Cr}$ and $\mathrm{Mn} / \mathrm{Cr}$ ratios for 88 Alberta crude oils analyzed by Hitchon et al. (1975). Some freshwater $b a$ oils and a Libyan oil analyzed by Filby \& Shah (1975) showed, however, higher $\mathrm{Fe} / \mathrm{Cr}$ and $\mathrm{Mn} / \mathrm{Cr}$ ratios.

3. Finally, mantle-normalized abundances of hydrothermally enriched elements As, Mo, $\mathrm{Ag}$, and $\mathrm{Pb}$ in the oils are orders of magnitude higher than the elements of the first group (about 1000), reflecting their enrichment by hydrothermal processes.

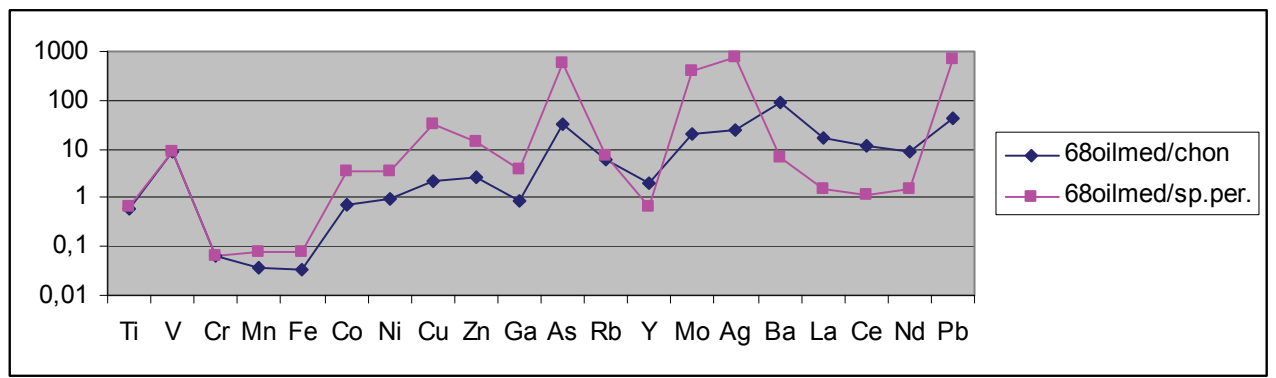

Fig. 18. Medians of 68 Brazilian oils (ppb) normalized to chondrite and to spinel peridotite mantle (ppm).

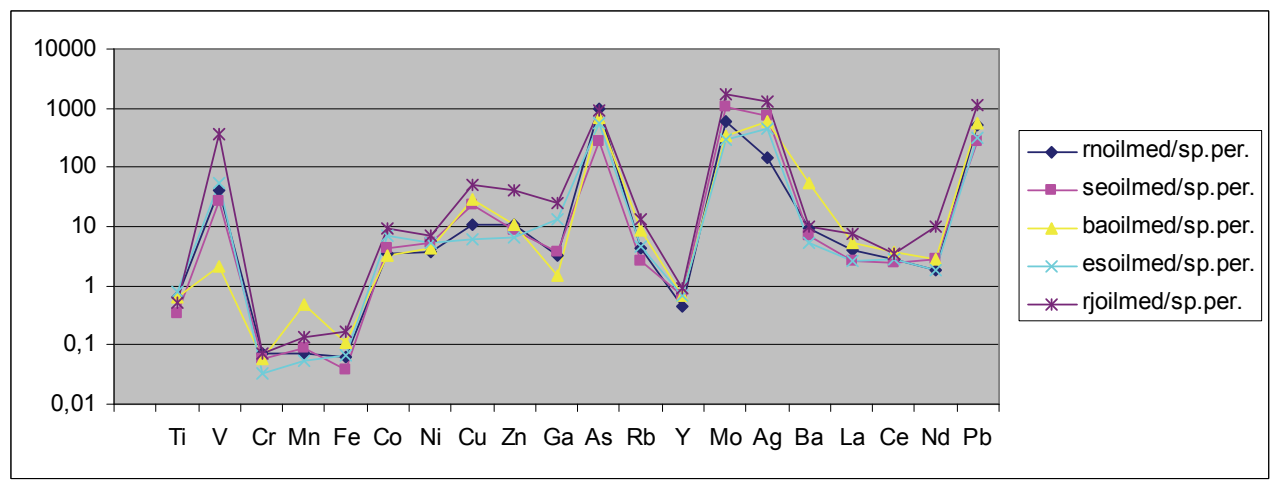

Fig. 19. Median trace metal abundances of oils ( $\mathrm{ppb}$ ) from five Brazilian basins normalized to spinel peridotite mantle (ppm). The plateau of mantle-derived elements Group I is about $10 \mathrm{ppb} / \mathrm{ppm}$, that of Group II (Cr, Mn, Fe) about $0.1 \mathrm{ppb} / \mathrm{ppm}$, and that of the hydrothermally enriched elements (As, Mo, Ag, $\mathrm{Pb}$ ) about $1000 \mathrm{ppb} / \mathrm{ppm}$.

\subsection{Correlations of trace element compositions with serpentinized fertile peridotite}

Serpentinized mantle peridotite shows even better correlation with the oils (Fig. 20) than the non-hydrated mantle shown above (Fig. 19). We used the geologic reference material UB-N, a serpentinized fertile peridotite from Col de Bagnelle in the Vosges Mountains, France, that was repeatedly analyzed in many laboratories for major and trace element concentrations (Govindaraju, 1982, 1995). Their Re-Os isotope systematics are now well understood, attesting to a serpentinized fertile upper mantle garnet-spinel peridotite (Meisel et al., 2003). 
Textural and mineral chemistry data suggest that the UB-N serpetinite originally formed in the garnet peridotite stability field at high pressure and subsequently re-equilibrated in the spinel peridotite stability field (Meisel et al., 2003). The serpentinizing fluid was a seawaterderived brine as indicated by the high $(600 \mathrm{ppm}) \mathrm{Cl}$ content of the serpentinite. As and $\mathrm{Pb}$, presumably introduced by the seawater-derived serpentinizing brine, are enriched by two orders of magnitude, Mo by one order of magnitude relative to fertile peridotites and the primitive mantle (McDonough et al., 1995).

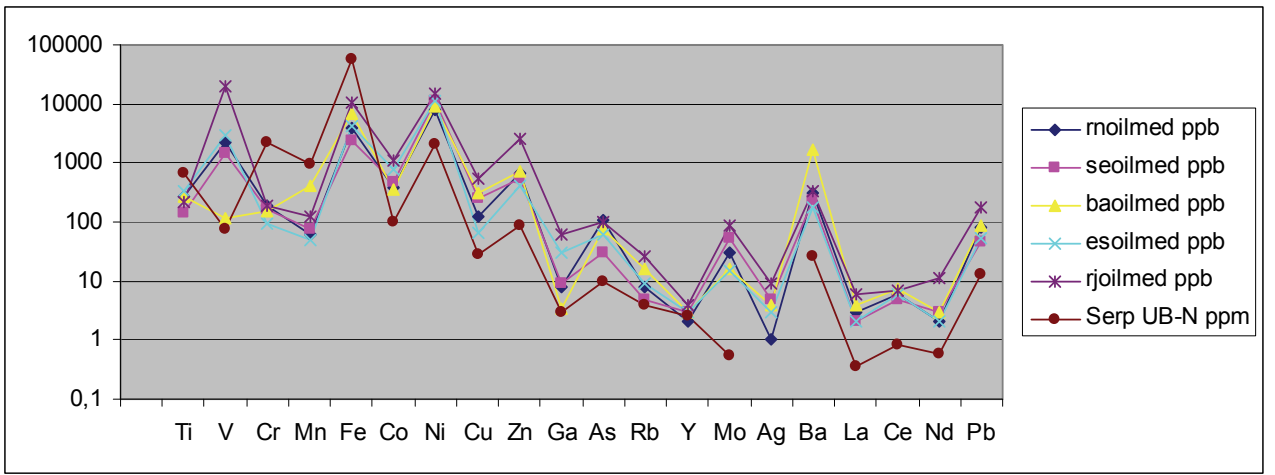

Fig. 20. Median trace elements distributions (ppb) in oils from five Brazilian basins, compared to serpentinized mantle UB-N. Note close parallelism.

When the trace element compositions of our oil samples are normalized to this serpentinized peridotite (Fig. 21, pink), the medians of the hydrothermally enriched elements join the mantle derived elements Group I on the same plateau. Thus, normalized to UB-N serpentinite/1000, the median abundances of the elements we analyzed in the Brazilian oils form only two plateaux: one near 10 for $\mathrm{V}, \mathrm{Co}, \mathrm{Ni}, \mathrm{Cu}, \mathrm{Zn}, \mathrm{Ga}, \mathrm{As}, \mathrm{Mo}, \mathrm{Ba}, \mathrm{La}$, $\mathrm{Ce}, \mathrm{Nd}, \mathrm{Pb}$, and another near 0.1 for $\mathrm{Fe}, \mathrm{Cr}$, and $\mathrm{Mn}$ (Ti lies between the two levels).

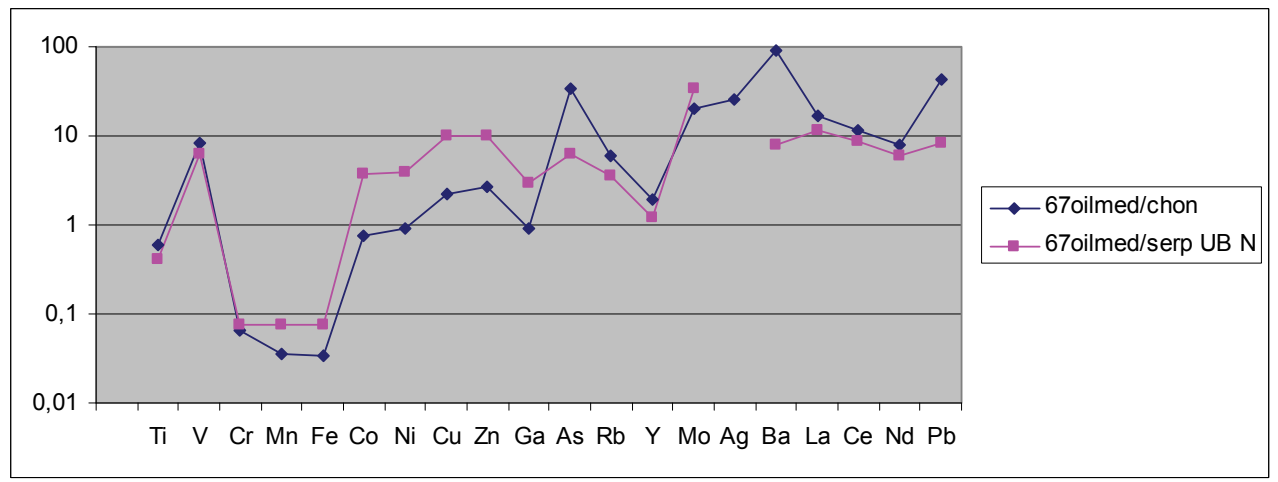

Fig. 21. Median trace element abundances of 67 Brazilian oils (ppb) normalized to chondrite/1000 and to serpentinized fertile mantle peridotite UB-N/1000. Values are in ppb for the oils, in ppm for the earth reservoirs. Note rising values when normalized to chondrite and a plateau near 10 for most elements when normalized to serpentinized mantle UB-N. 


\section{Abiogenic sources of trace metals and hydrocarbons}

\subsection{Carbonaceous chondrites}

The ten-years-old Tagish Lake meteorite, recovered in pristine condition over lake ice in Canada, is a new type of water and carbon-rich Type 2 carbonaceous chondrite that contains about $5 \%$ total carbon, of which the organic carbon reaches $1.3 \mathrm{wt}$. \%. The temperature of the meteorite has not risen above $120^{\circ} \mathrm{C}$ since the formation of the organics (Brown et al.,2000; Nakamura et al., 2003). It contains aliphatic hydrocarbons including both saturated and cyclic and/or unsaturated species, with peak abundance of normal alkanes at $\mathrm{C}_{23}$ and $\delta^{12} \mathrm{C}$ in the terrestrial range at -18 to -29 per mil. Carboxylic acids and n-alkanes in the meteorite display a distinct linear chain preference suggesting catalytic surface processes accompanied by aqueous processing of minerals on the parent body forming serpentine and saponite (Pizzarello et al., 2001).

\subsection{Serpentinizing mantle peridotites}

Rising hydrogen was observed in shallow pools over outcropping peridotites in Oman (Neal \& Stanger, 1983). Using seawater in experiments to serpentinize oceanic peridotites at temperatures of $200^{\circ} \mathrm{C}$ and $300^{\circ} \mathrm{C}$, at a pressure of 500 bar, and in the absence of $\mathrm{CO}_{2}$, Janecky \& Seyfried (1986) observed magnetite precipitation and significant hydrogen production as water was reduced by the oxidation of $\mathrm{Fe}^{2+}$ ions. In nature, serpentinization in the absence of $\mathrm{CO}_{2}$ generates hydrogen and creates one of the most reducing geologic environments on the Earth's surface, in which oxygen fugacities drop to the IW (iron-wüstite) buffer. Most of $\mathrm{Fe}, \mathrm{Cr}$, and $\mathrm{Mn}$ (and part of $\mathrm{Ti}$ ) in serpentinizing peridotite are immobilized in magnetite and other spinels that form during the serpentinization process, whereas most of the other trace elements pass into serpentine minerals (antigorite, lizardite) or into aqueous solutions. Part of $\mathrm{Ni}$ and $\mathrm{Fe}$ become reduced to metallic awaruite $\left(\mathrm{Ni}_{3} \mathrm{Fe}\right)$ and other $\mathrm{Ni}-\mathrm{Fe}$ alloys that have been found extensively in outcropping serpentinite bodies (Alt \& Shanks, 1998). These metals are widely used in the industry as hydrogenation catalysts (Pajonk \& Teichner, 1986); their presence during serpentinization is essential for the production of methane-rich hydrothermal fluids from dissolved $\mathrm{CO}_{2}$ (McCollom \& Seewald, 2001).

Serpentinization results from the hydration of peridotites at temperatures below $600^{\circ} \mathrm{C}$; it is favored by tectonic deformation as in collision zones and in active oceanic and continental rifts (O'Hanley, 1996). The circulation of water is controlled mostly by thermal convection: colder water (seawater or fresh water) sinks into the partially unroofed peridotites, heats up, and rises back along faults. Oceanic serpentinization results in considerable water increase, local $\mathrm{CaO}$ decrease, and uptake of trace amounts of $\mathrm{Sr}$ by the peridotites while the rare earth elements remain immobile (Scambelluri et al., 2001). The Ocean Drilling Project demonstrated the presence of an extensive ridge of tectonically exhumed and serpentinized mantle peridotites that formed during Mesozoic breakup along the continental margin of Iberia, where the sedimentary sequence is anomalously thin (Boillot et al., 1989; Whitmarsh et al., 1998, 2001; Beard et al., 2002, Manatschal, 2004) and where the role of shear zones channeling fluid flow during serpentinization was demonstrated by oxygen isotope studies (Skelton \& Valley, 2000). Skelton et al. (2003) suggest that syntectonic serpentinization also aided the transition from pure shear to simple shear rifting, the latter suggested also along the South Atlantic rifted margins. If dissolved $\mathrm{CO}_{2}$ is present during serpentinization, it reacts with the molecular hydrogen generated, forming formate and methane (Berndt et al., 1996; Horita \& Berndt, 1999, McCollom \& Seewald, 2001). Heavier hydrocarbons may also form. 
Szatmari (1989) suggested that serpentinization of the mantle provided major contributions of hydrogen, hydrocarbon liquids, and metals to petroleum formation by FTTS near plate boundaries and proposed that $\mathrm{Ni}$, a metal rare in the continental crust but abundant in petroleum, may derive from serpentinizing mantle peridotites. The evolution of the abiogenic model based on serpentinization of the mantle was presented by Szatmari et al. at successive meetings of the Geological Society of America (2004), the American Association of Petroleum Geologists Hedberg Research Conference on Origin of Petroleum -- Biogenic and/or Abiogenic and Its Significance in Hydrocarbon Exploration and Production (2005; Katz et al., 2008), the American Geophysical Union (2003, 2010), the International Meeting of Organic Geochemistry (2007), the International Geological Congress (2008) and Goldschmidt Conferences (2009, 2010).

FTTS over oceanic serpentinites was demonstrated in the Rainbow (Holm and Charlou, 2001) and Lost City hydrothermal fields at the Mid-Atlantic ridge. In the ultramafic, reduced, lowtemperature environment of the off-axis Lost City Hydrothermal Field (LCHF), where exothermic serpentinization reactions are believed to drive hydrothermal activity, rich microbial activity developed in the hydrogen and methane-rich environment. Hydrothermal plumes rising over serpentinizing peridotites contain abundant hydrogen, methane, and aliphatic hydrocarbons in the $\mathrm{C}_{16}-\mathrm{C}_{29}$ range, formed by FTTS (Holm \& Charlou, 2001, Kelley et al., 2001; Shrenk et al., 2002; Früh-Green et al, 2003; Kelley, 2005; Proskurowski et al., 2008; Bach and Früh-Green, 2010). In a high-temperature $\left(364^{\circ} \mathrm{C}\right)$ water plume rich in hydrogen and methane, in the Rainbow hydrothermal field where the Mid-Atlantic Ridge is intersected by an active fault zone that exposes serpentinizing peridotite rocks, Holm \& Charlou (2001) reported normal paraffins with chain lengths of 16 to 29 carbon atoms formed by FTTS. This finding, together with the discovery of aliphatic and cyclic hydrocarbons in the Orgueil meteorite and in the more recent pristine Tagish Lake meteorite (Pizzarello et al., 2001; Nakamura et al., 2003), as well as new studies on hydrocarbon stability at high P-T conditions (Kenney et al., 2002), gave renewed stimulus to the abiogenic models.

\subsection{Serpentinizing basalts}

Alteration of basaltic rocks by groundwater or seawater may also contribute to hydrogen generation and base metal mobility (Seewald \& Seyfried, 1990; Sacoccia et al., 1994; Stevens \& McKinley, 1995). In the outcropping Columbia River basalt, hydrogen generation may be impeded by the inflow of surface waters in equilibrium with the atmosphere. Experiments found small amounts of $\mathrm{H}_{2}$ produced at $\mathrm{pH} 6$ but not at $\mathrm{pH} 8$, whereas the $\mathrm{pH}$ of groundwater in basalt aquifers is buffered about 8 (Anderson et al., 1998). This is because the breakdown of minerals unstable at low temperatures consumes $\mathrm{H}^{+}$and releases $\mathrm{Ca}$ and $\mathrm{HCO}_{3}$ precipitating $\mathrm{CaCO}_{3}$. Geochemical modeling by Wallendahl \& Treiman (1999) also showed that if the basalts are open to ground water inflow carrying $\mathrm{CO}_{2}$ and $\mathrm{O}_{2}$, as in the case of the Columbia River basalt, then abundant calcium carbonate will form, buffering $\mathrm{pH}$ at 8 , so that production of molecular hydrogen by reduction of water and oxidation of $\mathrm{Fe}$ and Fe-Mg silicates will be minimal. If, however, the system is closed, serpentine and clay minerals will predominate as alteration products and abundant $\mathrm{H}_{2}$ will be produced, so that hydrocarbons may form by FTTS from the $\mathrm{CO}_{2}$ already present in the reservoirs. Chapelle et al. (2002) describe a unique hydrogen-consuming, methane-producing subsurface microbial community from Idaho, sustained by hydrogen rising with hydrothermal waters circulating in deeply buried igneous rocks. 


\subsection{A model of rising fluids carrying hydrogen, hydrocarbon, and metals}

It has not been established when metallation occurs in the diagenetic conversion of chlorophyll to metalloporphyrin, or the mechanism by which the reaction takes place (Filby, 1994). During the formation of some metalliferous black shales there are indications for an additional, hydrothermal source of the chalcophilic metals and platinum group elements, hence it is conceivable that metals in kerogen-rich shales and petroleum also derive, in part, from non-sedimentary sources. These may include hydrogen- and hydrocarbon-bearing hydrothermal fluids formed as Fe(II)-bearing mantle minerals react with water and carbon compounds, either deep in the mantle (Kenney et al., 2002) or during serpentinization. Metals in the rising fluids may be carried as chelated complexes or transported as ionic solutions. Below we briefly outline a model that derives a significant portion of both trace metals and hydrocarbons in petroleum and kerogen-rich shales from hydrothermal serpentinization of peridotites.

During strong deformation of the mantle lithosphere, as by rifting or initial subduction, cold water descends along faults, shear zones and breccias into partially unroofed, deforming mantle peridotites, causing serpentinization. Fe(II) in the peridotites and associated basalts becomes oxidized by the infiltrating water while hydrogen is generated creating a strongly reducing environment. In this hydrogen-rich environment, reduced carbon species including hydrocarbon gases and liquids of varying chain lengths may form at $200-300^{\circ} \mathrm{C}$ from carbonaceous and $\mathrm{CO}_{2}$ inclusions in the peridotites by Fischer-Tropsch-type synthesis, catalyzed by $\mathrm{Fe}-\mathrm{Ni}$ alloys such as awaruite, often present in serpentinized peridotites. Heteroatomic C, S, and N compounds introduced by the infiltrating water or forming in situ may be chelated by metals from the peridotites in approximately mantle-like proportions; other metals may be transported in ionic solution. Where the infiltrating fluid is seawater rich in sulfates, or basalts are abundant, sulfide activity and with it $\mathrm{V}$ rises while Co falls relative to $\mathrm{Ni}$, raising $\mathrm{V} / \mathrm{Ni}$ (and to a lesser extent $\mathrm{Mo} / \mathrm{Ni}$ and $\mathrm{Ga} / \mathrm{Ni}$ ) ratios from mantlelike toward crustal and seawater values.

Rapid rise of the fluid at high pressures, from deeply buried, serpentinizing peridotites, may permit hydrocarbons formed by FTTS to reach the sedimentary sequence uncracked but undergoing cyclicization and aromatization, forming new oil deposits or adding to existing ones. The rising fluid may interact with kerogen-rich shales that adsorb heavier hydrocarbons and metal-bearing polar and heteroatomic compounds from it while enriching it in biomarkers and biogenic hydrocarbons desorbed from the shales, creating the impression that these are the only source of all oil and metals in the oils. Adsorption and asphaltene precipitation increase, desorption decreases upward with decreasing temperatures and pressures. Hydrogen also decreases upward in the sediment column, increasing oxidation and polymerization of the transported organic matter that is being added to the fossil kerogen. A bacterial biota may feed on these fluids at depth, as shown for the Lost City vent field (Kelley et al., 2005). Part of the hydrogen and hydrocarbon-bearing fluid may seep through the sediments into the aquifer leading, in isolated basins, to the deposition of new organic and metal-rich shales.

\section{Conclusions}

Inorganic chemical evidence indicates a relationship between mantle and petroleum. 24 trace elements were analyzed by ICP-MS in 68 oils (one of them heavy), sampled from oil- 
producing sedimentary basins over the subcontinent of Brazil that produces more than 2 million barrels of oil per day. The analyses showed good correlation of the oils with CI chondrite and mantle peridotites, worse correlation with oceanic and continental crust, and none with seawater.

Mantle-normalized abundances of $\mathrm{Co}, \mathrm{Ni}, \mathrm{Cu}, \mathrm{Zn}, \mathrm{Ga}, \mathrm{La}, \mathrm{Ce}, \mathrm{Nd}$ are similar to each other, indicating a common, mantle origin; $\mathrm{V}$ is variable. Normalizing the oils to serpentinized mantle also includes the hydrothermally mobile elements $\mathrm{As}, \mathrm{Ag}, \mathrm{Mo}, \mathrm{Pb}$ with this group. Mantle-normalized $\mathrm{Cr}, \mathrm{Mn}$, and $\mathrm{Fe}$ are also similar to each other but their abundances are two orders of magnitudes lower than those of other mantle-derived elements, reflecting their lesser availability from secondary magnetite and other minerals that formed during serpentinization.

In the thermally cracked light oils of the Amazon-Solimões basin, affected by Juro-Triasssic subvolcanic and hydrothermal activity, the asphaltene-related elements $\mathrm{V}$ and Co abundances are more than a hundred times, Ni forty times, Ga, Mo, and As two to four times less than the median of the Brazilian oils, whereas $\mathrm{Cu}, \mathrm{Zn}$, and $\mathrm{Pb}$ abundances are two to four times above that median.

The dispersion of $\mathrm{V}$ values in our dataset, defined as the ratio of the third and first quartiles, is one to two orders of magnitudes higher than that of any other trace element including Ni. This leads to wide variation in the $\mathrm{V} / \mathrm{Ni}$ ratios which are chondritic to mantle-like in most Brazilian oils but rise to crustal levels in the $r j$ oils and in most of the major foreign oils we analyzed. Although Ni reaches high levels of about 10,000 ppb in oils of both the aborted Recôncavo rift and the passive margin, the corresponding $\mathrm{V}$ contents differ by orders of magnitude. Such wide variation may reflect differences in $\mathrm{pH}$, redox conditions and sulfide activity in the depositional environment of source shales, as proposed by the biogenic-synsedimentary model (Lewan \& Maynard, 1982; Lewan, 1984), or high activity of V-bearing organisms in certain marine environments (Curiale, 1987). Alternatively, the variation may be due to differences in the sulfate content of the water infiltrating through the rifted crust and causing serpentinization in shallow mantle peridotites. In the freshwater Reconcavo rift, where the water available for infiltration into the lithosphere is sulfate-poor and basaltic rocks are absent, the oils are poor in V (about $100 \mathrm{ppb}$ ). Conversely, along the passive margin and especially near the southern barrier of the South Atlantic Aptian evaporite basin, where the infiltrating water is sulfate-rich seawater and basalts are abundant, the $\mathrm{V}$ content of the oils reaches and exceeds their Ni content, raising $\mathrm{V} / \mathrm{Ni}$ ratios to crustal and sea water values. Sulfate reduction during serpentinization would decrease the availability of $\mathrm{Ni}$ (and $\mathrm{Co}$ ), but not of $\mathrm{V}$ (and Ga, Mo) that do not form sulfides, in the same way as suggested for the synsedimentary availability of these metals by Lewan \& Maynard (1982) and Lewan (1984). There appears to exist a worldwide correlation between the $\mathrm{V} / \mathrm{Ni}$ ratio and the size of petroleum reserves, with the richest oil provinces generally having the highest V/Ni ratio (Persian Gulf, Venezuela, Campos basin in Brazil). Hydrogen and hydrocarbons form when bivalent Fe in mantle peridotites is oxidized by water in the presence of $\mathrm{CO}_{2}$. This process may take place both at high (Gold, 1999; Kenney et al., 2002) and low P-T conditions. At high pressures and temperatures water, carbonates, and organic carbon are introduced by subducted slabs into the Earth's interior, whereas at low P-T conditions infiltrating water carrying dissolved organic and inorganic carbon compounds serpentinizes faulted and partially unroofed subcontinental mantle peridotites. In this paper we explored this second process. Hydrothermal plumes bearing aliphatic 
hydrocarbons and rising over serpentinizing peridotites in the Rainbow field at the MidAtlantic ridge (Holm \& Charlou, 2001) and aliphatic and cyclic hydrocarbons contained in the serpentinized material of the Tagish Lake meteorite (Pizzarello et al., 2001) may serve as possible analogs.

Heteroatomic organic compounds introduced with the infiltrating water into or forming in the hydrogen-rich environment of serpentinization may take up transition metals and rare earth elements from peridotites in approximately mantle-like proportions (Szatmari et al., 2000, 2002). Metals in organic compounds and in ionic solution rise with the hydrogen- and hydrocarbon-bearing hydrothermal fluids along faults from the serpentinizing peridotites into the sedimentary sequence, where they may enter petroleum reservoirs, become partially adsorbed by clay-rich shales during diagenesis, or seep to the surface. The details and partition coefficients of such metal transport are still poorly known.

Thus an internally consistent model can be conceived, deriving a major part of trace metals in the oils from mantle peridotites reacting with water, either at lower temperatures during serpentinization, or in the deeper mantle. The internal coherence of the model needs to be weighed carefully against the enormous database of the standard model which favors a sedimentary origin for both metals and hydrocarbons in petroleum. Systematic analysis of metals in algal-bacterial organic matter (including bacteria living over serpentinizing peridotites), hydrocarbons from the Tagish Lake meteorite (Pizzarello et al., 2001), and hydrocarbon-bearing plumes rising over serpentinizing peridotites near the Mid-Atlantic Ridge (Holm \& Charlou, 2001) will help to distinguish contributions from the various sources.

\section{Acknowledgements}

We thank Petrobras for support and permission to publish.

\section{References}

Alt, J. C., \& Shanks, W. C. III. (1998). Serpentinization processes and microbial sulfate reduction. Journal of Geophysical Research, 103, 9917.

Anders, E., \& Grevesse N., (1989). Abundances of the elements: Meteoritic and solar. Geochimica Cosmochimica Acta, 53, 197-214.

Anderson, R.T., Chapelle, F.H. \& Lovley, D.R. (1998). Evidence against hydrogen-based microbial ecosystems in basalt aquifers. Science 281, 976-977.

Bach, W. \& Früh-Green, G.L. (2010) Alteration of the oceanic lithosphere and implications for seafloor processes: Elements v. 6(3), 173-178.

Baker, E.W. \& Louda, J.W., (1986). Porphyrins in the geological record. In: Johns, R.B. (ed.) Biological Markers in the Sedimentary Record, Amsterdam: Elsevier, 125-225.

Ball, J.S., Wenger, W.J., Hyden, H.J., Horr, C.A. \& Myers, A.T. (1960). Metal content of twenty-four petroleums: Journal of Chemical and Engineering Data 5, 553-557.

Barwise, A.J.G. \& Whitehead, E.V. (1983). Fosssil fuel metals. In: Augustithis, S.S. (ed.) The significance of trace elements in solving petrogenic problems and controversies. Athens: Theophrastus Publications, 599-643.

Beard, J.S., Fullagar, P.D. \& Sinha, A.K. (2002) Gabbroic pegmatite intrusions, Iberia abyssal plain, ODP Leg 173, Site 1070: Magmatism during a transition from non-volcanic rifting to sea-floor spreading. Journal of Petrology 43, 885-905. 
Berndt, M. E., D. E. Allen \& Seyfried, W. E., Jr. (1996). Reduction of $\mathrm{CO}_{2}$ during serpentinization of olivine at $300 \mathrm{KC}$ and 500 bar. Geology 24, 351-354.

Berthelot, M., (1866). Sur l'origine des carbures et des combustibles minéraux. Ann. de Chimie et des Physiques 4. ser. 9, 481-483.

Boillot, G., G., Féraud, M. Recq \& Girardeau, J. (1989). Undercrusting by serpentinite beneath rifted margins: Nature 341, 523-525.

Broeker, W. S., \& Peng, T.-H. (1982). Tracers in the Sea. Eldigio Press.

Brown, P. G.,Hildebrand, A. R., Zolensky, M. E., Grady, M., et al., (2000) The Fall, Recovery, Orbit, and Composition of the Tagish Lake Meteorite: A New Type of Carbonaceous Chondrite. Science, 290, 320-325.

Brumsack, H,.-J. (2003). Major and minor element geochemistry of black shales from the Cenomanian Turonian Boundary Event (CTBE). Paleoenvironmental constraints. Ocean Drilling Project, Contributions, University of Oldenburg, Institute of Microbiochemistry http:/ / eagle.icbm.uni-oldenburg.de

Cainelli, C. \& Mohriak, W.U.(1998). Geology of Atlantic Eastern Brazilian Basins (Short Course, Coordinator M. Carminatti): AAPG International Conference $\mathcal{E}$ Exhibition, Rio de Janeiro, Brazil, $67 \mathrm{p}$.

Chapelle, F.H., O’Neill, K., Bradley P.M., Methé, B.A., Clufo, S.A., Knobel, L.L. \&Lovley, D.R. (2002). A hydrogen-based subsurface microbial community dominated by methanogens. Nature 415, 312-315.

Charlou, J. L., Fouquet, Bougalt, Y. H., Donval, J. P., Etoubleau, J., Ph.Jean-Baptiste, Ph., Dapoigny, A., Appriou, P. \& Rona, P. S. (1998). Intense $\mathrm{CH}_{4}$ plumes generated by serpentinization of ultramafic rocks at the intersection of the $15^{\circ} 20^{\prime} \mathrm{N}$ fracture zone and the Mid-Atlantic Ridge: Geochimica Cosmochimica Acta 62, 2323-2333.

Curiale, J.A., (1987). Distribution and occurrence of metals in heavy crude oils and solid bitumens implications for petroleum exploration. In: Meyer, R.F. (ed.) Exploration for heavy crude oil and natural bitumen. AAPG Studies in Geology 25, 207-219.

Curiale, J.A. (1993). Occurrence and significance of metals in solid bitumens: an organic geochemical approach. In: Parnell, J., Kucha, H., \& Landais, P. (eds.) Bitumens in ore deposits. New York: Springer-Verlag, 461- 474.

Dahl, J. E., Moldowan, J. M., Peters K. E. et al., (1999). Diamondoid hydrocarbons as indicators of natural oil cracking. Nature 399, 54-56.

Fedikow, M.A.F., Bezys, R.K., Bamburak, J.D., Conley, G.G. \& Garrett, R.G. (1998). Geochemical database for Phanerozoic black shales in Manitoba. Manitoba Energy and Mines, Geological Services, Open File Report OF98-2, 124 p. and one diskette.

Filby, R. H., (1975). The nature of metals in petroleum. In: Yen, T. F. (ed.) The Role of Trace Metals in Petroleum, Ann Arbor: Ann Arbor Science, 31-58

Filby, R. H., (1994). Origin and nature of trace element species in crude oils, bitumens and kerogens: implications for correlation and other geochemical studies. In: Parnell, J. (ed.) Geofluids: Origin, Migration and Evolution of Fluids in Sedimentary Basins. Geological Society of London Special Publications 78, 203-219.

Filby, R. H., \& Van Berkel, G. J. (1987). Geochemistry of metal complexes in petroleum, source rocks and coals: an overview. In: Filby R. H. \& Branthaver, J. F. (eds.) Metal Complexes in Fossil Fuels: Geochemistry, Characterization and Processing, American Chemical Society, 2-39. 
Filby, R. H., \& S. D. J. Olsen (1994). A comparison of instrumental neutron activation analysis and inductively coupled plasma-mass spectrometry for trace element determination in petroleum geochemistry. Radioanaytical and Nuclear Chemistry, 80, 285-294.

Filby, R.H. \& Shah, K.R., (1975). Neutron activation methods for trace elements in crude oils. In: Yen, T.F. (ed.) The Role of Trace Metals in Petroleum. Ann Arbor: Ann Arbor Science Publishers, 89-110.

Fischer, Franz (1925). The conversion of coal into oils, Ernest Benn, London.

Fonseca, T. C. Oliveira da (2000). Caracterização inorgânica dos petróleos brasilieros pela técnica de ICP-MS para fins de exploração geoquímica, Ph.D. thesis, P.U.C., Rio de Janeiro, $135 \mathrm{p}$.

Foustoukos, D.I. \& William E. Seyfried, W.E.,Jr.(2004). Hydrocarbons in hydrothermal vent fluids: The role of chromium-bearing catalysts. Science 304, 1002-1005.

Früh-Green, G.L., Kelley, D.S., Bernasconi, M., Karson, J.A., Ludwig, K.A., Butterfield, D.A., Boschi, C., Proskurowski, G. (2003). 30,000 years of hydrothermal activity at the Lost City vent field. Science 301, 495-498.

Gold, T., (1999). The deep hot biosphere. New York: Springer.

Govindaraju, K. (1982) Report (1967-1981) on four ANRT rock reference samples: diorite DR-N, serpentinite UB-N, bauxite BX-N and disthene DT-N. Geostandard Newsletter 6, 91-159.

Govindaraju, K. (1995). 1994 compilation of working values and sample descriptions for 383 geostandards. Geostandards Newsletter Special Issue 19, 1-32.

Granch, R.I. \& Huyck, H.L.O. (eds.) (1989). Metalliferous Black Shales and Related Ore Deposits. United States Geological Survey, Circular 1058.

Hitchon, B., Filby, R.H., \& Shah, K. (1975).Geochemistry of trace elements in crude oils, Alberta, Canada. In: Yen, T.F. (ed.) The Role of Trace Metals in Petroleum. Ann Arbor: Ann Arbor Science Publishers, 111-121.

Holm, N.G., \& Charlou, J. (2001). Initial indications of abiotic formation of hydrocarbons in the Rainbow ultramafic hydrothermal system, Mid-Atlantic Ridge. Earth and Planetary Science Letters 191, 1-8.

Horita, J., \& M.E. Berndt (1999). Abiogenic methane formation and isotopic fractionation under hydrothermal conditions. Science 285, 1055-1057.

Janecky, D. R., \& W. E. Seyfried (1986). Hydrothermal serpentinization of peridotite within the continental crust: Experimental investigations of mineralogy and major element chemistry. Geochimica Cosmochimica Acta 50, 1357-1378.

Jones, P., (1977) The presence of trace elements in crude oils and allied substances. Forum on Oil and Ore in Sediments, Proceedings, London: Imperial College 40-53.

Katz, B. J., \& M. R. Mello (2000). Petroleum systems of South Atlantic marginal basins - an overview. In: M. R. Mello \& B. Katz (eds.) Petroleum systems of South Atlantic margins, AAPG Memoir, 73, 1-14.

Kelley, D.S. et al., (2005).A serpentinite-hosted ecosystem: The Lost City hydrothermal field, Science 307, 1428-1444.

Kenney, J.F., Kutcherov, V.A., Bendeliani, N.A., \& Alekseev, V.A. (2002). The evolution of multicomponent systems at high pressures: VI. The thermodynamic stability of the hydrogen-carbon system, the genesis of hydrocarbons, and the origin of 
petroleum. Proceedings of the National Academy of Science, PNAS 2002 99: 1097610981; published online before print as 10.1073/pnas.172376899

Kevin K. Roe, Geoff T. Lebon, Pete Rivizzigno \& the AT3-60 Shipboard Party (2001). An offaxis hydrothermal vent field near the Mid-Atlantic Ridge at $30^{\circ}$ N. Nature 412, 145 149.

Lancet, M., \& E. Anders (1970). Carbon isotope fractionation in the Fischer-Tropsch synthesis and in meteorites: Science, 170, 980-982.

Lefebure, D.V. \& Coveney, R..M. Jr.(1995). Shale-hosted Ni-Zn-Mo-PGE. In: Selected British Columbia Mineral Deposit Profiles, Volume 1 - Metallics and Coal,

Lefebure, D.V. \& Ray, G.E. (eds.) British Columbia Ministry of Energy of Employment and Investment, Open File 1995-20, 45-48.

Lewan, M.D. (1997) Experiments on the role of water in petroleum formation. Geochimica Cosmochimica Acta 61, 3691-3723.

Lewan, M. D. (1984). Factors controlling the proportionality of vanadium to nickel; ratios in crude oils. Geochimica Cosmochimica Acta, 48, 2231-2238.

Lewan, M. D., \& Maynard, J. B. (1982). Factors controlling enrichment of vanadium and nickel in the bitumen of organic sedimentary rocks: Geochimica Cosmochimica Acta, 46, 2547-2560.

Louda, J.W. \& Baker, E.W. (1981). Geochemistry of tetrapyrrole, carotenoid and perylene pigments in sediments from the San Miguel Gap (Site 467) and Baja California Borderland (Site 471). In: Initial Reports of the Deep Sea Drilling Project, 63, 785- 818.

Manatschal G. (2004). New models for evolution of magma-poor rifted margins based on a review of data and concepts from West Iberia and the Alps. Int. J. Earth Sci., 93, 432466.

McCollom, T. M., \& Seewald, J. S. (2001). A reassessment of the potential for reduction of dissolved $\mathrm{CO}_{2}$ to hydrocarbons during serpentinization of olivine: Geochimica Cosmochimica Acta 65, 3769-3778.

McDonough, W.F., \& Sun, S.-S. (1995). The composition of the Earth. Chemical Geology 120, 223-253.

Meisel, T. Reisberg, L., Moser, J., Carignan, J., Melcher, F. \& Brügman, G. (2003). Re-Os systematics of UB-N, a serpentinized peridotite reference material, Chemical Geology, 201, 161-179.

Milani, E.J. \& Zalan, P.V. (1998).The geology of Paleozoic cratonic basins and Mesozoic interior rifts of Brazil. (Short Course, Coordinator M. Carminatti). AAPG International Conference \& Exhibition, Rio de Janeiro, Brazil, 184 p.

Nakamura et al. (2003) International Astrobiology 1, 179.

Neal, C., \& Stanger, G. (1983). Hydrogen generation from mantle source rocks in Oman: Earth Planetary Science Letters 66, 315-320.

O'Hanley, D., (1996) Serpentinites: Records of Tectonic and Petrologic History: Oxford University Press.

Pajonk, G. M., \& Teichner, S. J. (1986). Carrier effect on hydrogenation properties of Metals. In: L. Cerveny (ed.) Catalytic Hydrogenation. Amsterdam: Elsevier 277-304.

Pizzarello, S., Huang, Y., Becker, L., Poreda, R. J., Nieman, R. A., Coopeer, G. \& Williams, M. (2001). Science 293, 2236-2239. 
Proskurowski, G., Marvin D. Lilley,M.D., Seewald, J.S., Früh-Green, G.L. Olson, E.J., Lupton, J.E., S.P. and Kelley, D.S. (2008) Abiogenic hydrocarbon production at Lost City hydrothermal field: Science 319, no. 5863, pp. 604 - 607.

Quinby-Hunt, M. S., \& Turekian, K. K. (1983). Distribution of elements in sea water: EOS, p. 130-132.

Robinson, R., 1963, Duplex origin of petroleum: Nature, 199, 113-114.

Rudnick, R. L., \& Fountain, D. M. (1995). Nature and composition of the continental crust - a lower crustal perspective: Review of Geophysics, 33, 267-309.

Saccocia, P.J., Ding K., Berndt M.E., Seewald J.S. \& Seyfried W.E. Jr. (1994). Experimental and theoretical perspectives on crustal alteration at mid-ocean ridges. In: Lentz, D.R. (ed.) Alteration Processes Associated with Ore-forming Systems. Geological Association of Canada, Short Course Notes 11, 403-431.

Scambelluri, M., Rampone, E. \& Piccardo, G.B. (2001). Fluid and element cycling in subducted serpentinite: a trace-element study of the Erro-Tobbio high-pressure ultramafites (western Alps, NW Italy). Journal of Petrology 42, 55-67.

Schiefelbein, C.F., Zumberge, Cameron, N.C., \& Brown, S.W. (2000). Geochemical comparison of crude oil along South Atlantic margins. In: M. R. Mello \& B. Katz (eds.) Petroleum systems of South Atlantic margins, AAPG Memoir, 73, 1-14.

Seewald, J.S. \& Seyfried W.E. Jr. (1990). The effect of temperature on heavy and base metal mobility in subseafloor hydrothermal systems: constraints from basalt alteration experiments and field studies. Earth Planetary Science Letters 101, 388-403.

Shrenk, M.O., Cimino, P., Kelley, D.S., \& Baross, J.A. (2002). Microbial diversity of carbonate chimneys at the Lost City Hydrothermal Field: Implications for lifesustaining systems in peridotite seafloor environments. American Geophysical Union, Fall Meeting Abstract \#B71B-0742.

Skelton, A., Koyi, H., Whitmarsh, R., \& Arghe, F. (2003). Extent, rate, timing and implications of serpentinization at the zone of exhumed continental mantle, west of Iberia. EGS - AGU - EUG Joint Assembly, Nice, France, Abstract \#5038.

Skelton A.D.L. \& Valley, J.W. (2000). Earth Planetary Science Letters 178, 327-338.

Speight, J.G. \& Long, R.G. (1996). The concept of asphaltenes revisited. Fuel Sci. \& Tech. Int. $14,1-12$.

Stevens, T.O. \& McKinley, J.P. (1995). Lithoautotrophic microbial ecosystems in deep basalt aquifers. Science 270, 450-454

Strong, D. \& R.H. Filby, (1987). Vanadylporphyrin distribution in the Alberta oil-sand bitumens. In: R.H. Filby \& J.F. Branthaver (eds) Metal Complexes in Fossil Fuels: Geochemistry, Characterization and Processing. American Chemical Society, 154-172.

Szatmari, P. (1989). Petroleum formation by Fischer-Tropsch synthesis in plate tectonics. AAPG Bulletin 73, 989-998.

Szatmari, P. (2000). Habitat of petroleum along South Atlantic margins. In: Mello, M.R. \& Katz B. (eds.) Petroleum systems of South Atlantic margins. AAPG Memoir 73, 69- 76.

Szatmari, P., T. C. Oliveira da Fonseca, N. F. Miekeley (2000). Trace metals in petroleum derived from serpentinizing peridotites. Geological Society of America Annual Meeting, Reno, Nevada, 9-18 Nov 2000.

Szatmari, P., T. C. Oliveira da Fonseca, N. F. Miekeley (2002). Petroleum formation during serpentinization: the evidence of trace elements: American Geophysical Union Spring Meeting, Washington, 13-15 May, 2002. 
Szatmari, P., T.C. Oliveira da Fonseca, N.F. Miekeley (2005) Trace element evidence for major contribution to commercial oils by serpentinizing mantle peridotites. AAPG Research Conference "Origin of Petroleum-Biogenic and/or abiogenic and its significance in hydrocarbon exploration and production", Calgary, Canada.

Takahiro, H., Zolensky, M. E., Pieters, C. M. (2000) The Tagish Lake meteorite: A possible sample from a D-type asteroid. Science 293, 2234-2236.

Tissot B.P. \& Welte, D.H. (1984) Petroleum formation and occurrence - second revised and enlarged edition. Berlin: Springer Verlag, $699 \mathrm{p}$.

Valkovic, V. (1978) Trace elements in petroleum. Tulsa: Petroleum Publishing, 269 p.

Treibs, A., 1934, 1935, Chlorophyll- und Häminderivate in bituminosen Gesteinen, Erdöl, Erdwachsen und Asphalten, Annalen der Chemie 509, 103-114 (1934); 510, 42- 62 (1934); 517, 172-196 (1935).

United States Geological Survey Central Region Mineral Resources Team (2003) URL: http:// minerals.cr.usgs.gov/projects/brines/task2.html

Wallendahl, A. \& Treiman, A.H. (1999).Geochemical models of low-temperature alteration of Martian rocks. [Abstract \#1268] Lunar and Planetary Science Conference XXX, LPI Contribution No. 964, Lunar and Planetary Institute, Houston (CD-ROM).

Wedepohl, H., (1995). The composition of the continental crust: Geochimica Cosmochimica Acta 59, 1217-1239.

Whitmarsh, R. B., M. O. Beslier, P. J. Wallace et al. (1998). Proceedings of the Ocean Drilling Program, Initial Reports 173. College Station, Texas.

Whitmarsh, R.B., Manatschal G. \& Minshull, T.B. (2001). Nature 413, 150-154.

Wignall, P.B. (1994). Black shales. Geology and Geophysics Monographs 30. Oxford: Oxford University Press, $130 \mathrm{p}$.

Yen, T.F. (1975). Chemical aspects of metals in native petroleum. In: Yen, T.F. (ed.) The Role of Trace Metals in Petroleum. Ann Arbor: Ann Arbor Science Publishers, 1-30.

Zalán, P. et al. (2009) Stretching and Thinning of the Upper Lithosphere and ContinentalOceanic Transition in Southeastern Brazil, AAPG ICE Rio de Janeiro, Brazil. 


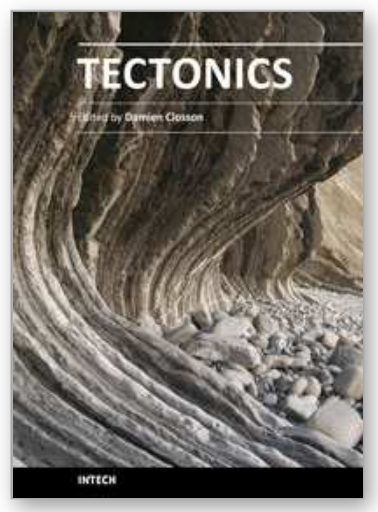

\author{
Tectonics \\ Edited by Dr. Damien Closson
}

ISBN 978-953-307-545-7

Hard cover, 358 pages

Publisher InTech

Published online 28, February, 2011

Published in print edition February, 2011

The term tectonics refers to the study dealing with the forces and displacements that have operated to create structures within the lithosphere. The deformations affecting the Earth's crust are result of the release and the redistribution of energy from Earth's core. The concept of plate tectonics is the chief working principle.

Tectonics has application to lunar and planetary studies, whether or not those bodies have active tectonic plate systems. Petroleum and mineral prospecting uses this branch of knowledge as guide. The present book is restricted to the structure and evolution of the terrestrial lithosphere with dominant emphasis on the continents. Thirteen original scientific contributions highlight most recent developments in seven relevant domains: Gondwana history, the tectonics of Europe and the Near East; the tectonics of Siberia; the tectonics of China and its neighbourhood; advanced concepts on plate tectonics are discussed in two articles; in the frame of neotectonics, two investigation techniques are examined; finally, the relation between tectonics and petroleum researches is illustrated in one chapter.

\title{
How to reference
}

In order to correctly reference this scholarly work, feel free to copy and paste the following:

Peter Szatmari, Teresa Cristina O. da Fonseca and Norbert F. Miekeley (2011). Mantle-like Trace Element Composition of Petroleum - Contributions from Serpentinizing Peridotites, Tectonics, Dr. Damien Closson (Ed.), ISBN: 978-953-307-545-7, InTech, Available from: http://www.intechopen.com/books/tectonics/mantlelike-trace-element-composition-of-petroleum-contributions-from-serpentinizing-peridotites

\section{INTECH}

open science | open minds

\section{InTech Europe}

University Campus STeP Ri

Slavka Krautzeka 83/A

51000 Rijeka, Croatia

Phone: +385 (51) 770447

Fax: +385 (51) 686166

www.intechopen.com

\section{InTech China}

Unit 405, Office Block, Hotel Equatorial Shanghai

No.65, Yan An Road (West), Shanghai, 200040, China

中国上海市延安西路65号上海国际贵都大饭店办公楼 405 单元

Phone: +86-21-62489820

Fax: $+86-21-62489821$ 
(C) 2011 The Author(s). Licensee IntechOpen. This chapter is distributed under the terms of the Creative Commons Attribution-NonCommercialShareAlike-3.0 License, which permits use, distribution and reproduction for non-commercial purposes, provided the original is properly cited and derivative works building on this content are distributed under the same license. 